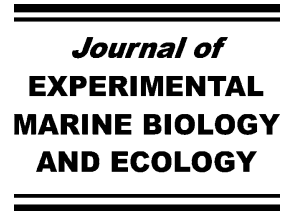

Journal of Experimental Marine Biology and Ecology 315 (2005) 49-69

www.elsevier.com/locate/jembe

\title{
Seasonal growth dynamics of Laurencia papillosa and Gracilaria coronopifolia from a highly eutrophic reef in southern Taiwan: temperature limitation and nutrient availability
}

\author{
Chuan-Chuan Tsai ${ }^{\mathrm{a}}$, Jui-Sheng Chang ${ }^{\mathrm{b}}$, Fuu Sheu ${ }^{\mathrm{c}}$, Yuang-Tay Shyu ${ }^{\mathrm{c}}$, \\ Amanda Yi-Chuan Yu ${ }^{\mathrm{a}}$, Saou-Lien Wong ${ }^{\mathrm{d}}$, Chang-Feng Dai ${ }^{\mathrm{e}}$, Tse-Min Lee ${ }^{\mathrm{a}, *}$ \\ anstitute of Marine Biology, National Sun Yat-sen University, Kaohsiung 80424, Taiwan, ROC \\ ${ }^{\mathrm{b}}$ Center of General Education, Yu Da University, Miaoli 361, Taiwan, ROC \\ ${ }^{\mathrm{c}}$ Department of Horticulture, National Taiwan University, Taipei 106, Taiwan, ROC \\ ${ }^{\mathrm{d}}$ Department of Aquaculture, National Pingtung University of Science and Technology, Pingtung 912, Taiwan, ROC \\ ${ }^{\mathrm{e}}$ Institute of Oceanography, National Taiwan University, Taipei 106, Taiwan, ROC
}

Received 16 March 2004; received in revised form 20 July 2004; accepted 31 August 2004

\begin{abstract}
Both field and laboratory studies were used to investigate the effects of temperature limitation and nutrient availability on seasonal growth dynamics of Laurencia papillosa and Gracilaria coronopifolia from a nearshore coral reef in the southern tip of Taiwan during 1999-2000. L. papillosa was a summer blooming alga abundant in August-November and G. coronopifolia was abundant year round except April-May. L. papillosa blooms in the summer were attributed to its preference for high temperatures and highly sensitivity to low temperatures. A wider temperature range and a significant stimulation of growth by high $\mathrm{N}$ inputs can explain the appearance of G. coronopifolia year round and also its maximum growth in November-March. Levels of dissolved inorganic nitrogen (DIN) and soluble reactive phosphorus (SRP) in water column were extremely high, but the growth of these two rhodophytes still suffered nutrient limitation that the type and severity of nutrient limitation were variable over time and also between two species. The growth of $L$. papillosa was limited by $\mathrm{P}$ in the early growth stage (August-September) as indicated by decreased tissue $\mathrm{P}$ contents, increased $\mathrm{C} / \mathrm{P}$ and N/P molar ratios and increased alkaline phosphatase activity (APA) and in the later growth stage, it was subjected to $\mathrm{N}$-limitation, evidenced by decreased tissue $\mathrm{N}$ contents and $\mathrm{C} / \mathrm{P}$ and $\mathrm{N} / \mathrm{P}$ molar ratios and increased tissue $\mathrm{P}$ contents. The growth of G. coronopifolia was also P-limited as indicated by increased tissue $\mathrm{N}$ contents and concomitantly decreased tissue $\mathrm{P}$ contents, while marked drops in tissue $\mathrm{P}$ contents below the subsistence level in mid September and December 1999 reveal severe P limitation, which was supported by increased alkaline phosphatase activity. Higher critical nutrient contents and nutrient thresholds for maximum growth of G. coronopifolia suggest that $G$. coronopifolia faced more frequent nutrient limitation compared to L. papillosa. In conclusion, the results from these laboratory and field studies provide evidence that the seasonal abundance of L. papillosa and G. coronopifolia from
\end{abstract}

\footnotetext{
* Corresponding author. Tel.: +886 7 5252000x5110; fax: +886 75251509.

E-mail address: tmlee@mail.nsysu.edu.tw (T.-M. Lee).
} 
southern Taiwan was determined by seasonal variations in seawater temperatures and nutrient concentrations as well as different physiological growth strategies. Seawater temperature and nutrient availability were important determinants of seasonal abundance of $L$. papillosa while the seasonal abundance of $G$. coronopifolia was influenced by nutrient availability.

(C) 2004 Elsevier B.V. All rights reserved.

Keywords: Gracilaria coronopifolia; Laurencia papillosa; Nutrient; Temperature

\section{Introduction}

Coral reefs in many tropical coastal waters are now undergoing a phase shift from coral to algae-dominated reef (Littler et al., 1992; Naim, 1993; Hughes, 1994; Lapointe, 1997). Field and laboratory experiments have suggested that nutrient enrichment is a determinant of coral reef community structure (NRC, 2000). In the mid-1970s, the impact of anthropogenic nutrient inputs on macroalgal blooms was first reported for the case of a green alga Dictyosphaeria cavernosa in Kaneohe Bay, Hawaii (Banner, 1974; Smith et al., 1981). The role of increasing watercolumn nutrient concentrations on algal blooms has been suggested at Reunion Island, Indian Ocean (Cuet et al., 1988) and in the Caribbean and Florida coastal regions (Lapointe and O'Connell, 1989; Bell, 1992; Lapointe et al., 1994). Evidently, algal blooms on coral reefs are associated with enhanced nutrient availability. However, studies showed that nitrogen $(\mathrm{N})$ and phosphorus (P) are nutrients limiting the productivity of macroalgae on coral reefs (Lapointe, 1987, 1997; Lapointe et al., 1987; Littler et al., 1991; Larned, 1998). The comparison of water-column inorganic nitrogen : phosphorus (N/P) ratios to algal tissue N/P ratios and the results of nutrient enrichment experiments indicate that the productivity of algae in Kaneohe Bay, Hawaii is limited by $\mathrm{N}$ instead of $\mathrm{P}$ (Larned, 1998). However, Lapointe (1997) showed primary P-limitation of macroalgal productivity on carbonate-rich reefs, Discovery Bay, Jamaican, that are enriched by submarine groundwater discharge of nitrate; in comparison, macroalgae were more $\mathrm{N}$ limited on siliiclastic reefs of southeast Florida where the water column is more enriched in soluble reactive phosphorus (SRP). It is evident that the type and severity of nutrient limitation are variable among habitats, species, and time (Lapointe, 1987; Lapointe et al., 1987).
Coastal regions along Hengchuan Peninsula in the southern tip of Taiwan, which is the most developed coral reef ecosystems in Taiwan, have now faced increasing pressure from expanded urban development and tourism populations. Most nearshore reefs in Hengchuan Peninsula are characterized by high abundance in fleshy macroalgae and low abundance in herbivorous fishes (Dai, 1997). These algal blooms are often composed of opportunistic algae in the genera Enteromorpha, Gracilaria, Laurencia, and Sargassum. It is known that the shift of coral reefs to algae-dominated reefs generally causes a dramatic decline in fish stocks and biodiversity in coral reef ecosystems (NRC, 2000). Thus, the understanding of macroalgal abundance on southern Taiwan coral reefs is an important aspect of the ecological, environmental, aesthetic and socio-economic value of the reefs. The qualitative observations carried out in 1998 have showed that two rhodophytes Laurencia papillosa and Gracilaria coronopifolia abundant on Hengchuan Peninsula had different seasonality: $L$. papillosa was abundant in the summer months (JulyOctober) while G. coronopifolia was abundant all the year except April-May (unpublished data). Both field and laboratory studies were conducted to determine whether the seasonal abundance of L. papillosa and G. coronopifolia from Hengchuan Peninsula was regulated by nutrient availability. In an effort to understand algal nutrient status and the type and severity of nutrient limitation over time, seasonal variations in seawater nutrient concentrations and algal tissue nutrient contents were analyzed and compared to the critical and subsistence nutrient contents. In addition, the determination of algal alkaline phosphatase activity (APA) as P deficiency indicator of coral reef algae (Lapointe, 1997) was included to assess the occurrence of $\mathrm{P}$ limitation. Because algal growth and morphology, distribution and seasonal abundance are affected by temperature 
(Garbary, 1979; Lüning, 1984; Breeman, 1988; Pakker et al., 1994; Davison and Pearson, 1996; Lee et al., 1999), the growth temperature range and optima, and also the interactions of nutrient and temperature on algal growth were determined by an exposure of algae to varying temperatures ranging from $15-35{ }^{\circ} \mathrm{C}$ in continuous-flow seawater enriched with or without nutrients to elucidate the influences of temperature fluctuations and nutrient availability on seasonal variations of biomass abundance of $L$. papillosa and G. coronopifolia.

\section{Materials and methods}

\subsection{Study site and environmental characters}

The field experiments were performed during January 1999-August 2000 on a nearshore coral reef (GPS: $21^{\circ} 56^{\prime} 00^{\prime \prime} \mathrm{N}$; $120^{\circ} 50^{\prime} 10^{\prime \prime} \mathrm{E}$ ) from Nanwan
Bay in southern Taiwan. Nanwan Bay is located at the western side of Hengchuan Peninsula, which is surrounded by the Pacific Ocean on the east coast, the Bashi Channel on the southern coast and the Taiwan Straits on the western coast (Fig. 1). This reef has a horizontal width of $1200 \mathrm{~m}$, composed of an intertidal region, approximately $50-130 \mathrm{~m}$ long, and a subtidal region, approximately 35-270 $\mathrm{m}$ long and a depth of 1-12 m (MHWS) in a seaward gradient. Two drainage outlets carrying fertilizers and sewage from croplands and residential areas near the study site were significant nutrient pollutant sources in this reef and their effects were profound during the rainfall period (May-September). The monthly survey during 19992000 showed that the concentrations of DIN $\left(\mathrm{NO}_{3}^{-}\right.$ and $\mathrm{NH}_{4}^{+}$as the main component) and SRP in drainage outlets were 19.2-95.6 and 3.7-19.8 $\mu \mathrm{M}$, respectively, with the peaks in June 1999 and MayJune 2000, which correlated with the precipitation pattern.

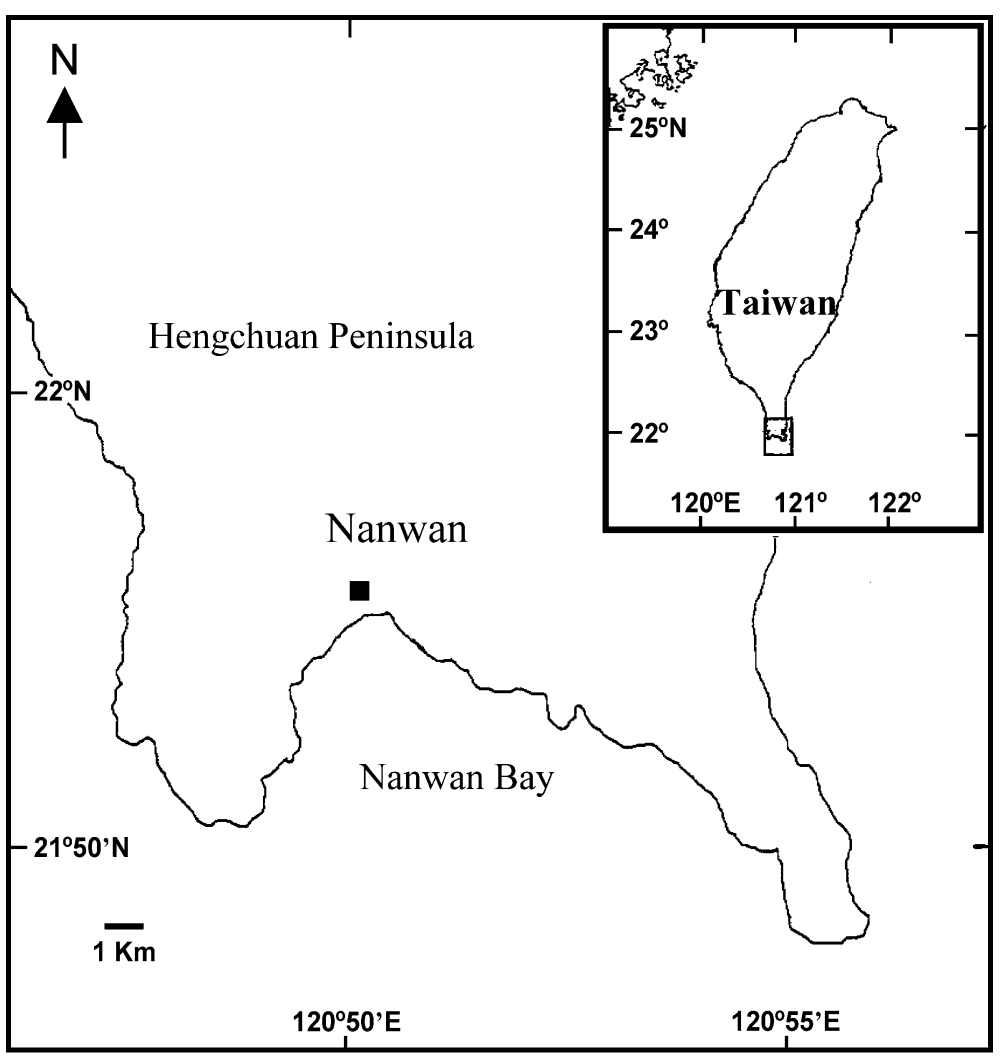

Fig. 1. Study site in southern Taiwan. 
The climate data (1960-1990) from the Central Weather Bureau of Taiwan of Republic of China showed that Hengchuan Peninsula has a warm tropical climate, the mean annual air temperature is $25{ }^{\circ} \mathrm{C}$ and the mean annual relative humidity is $77 \%$. Mean monthly air temperature is low in January $\left(20.3{ }^{\circ} \mathrm{C}\right)$ and high in July $\left(28.3{ }^{\circ} \mathrm{C}\right)$. The mean annual precipitation is $1964.9 \mathrm{~mm}$, mainly occurring during May-September with a peak in July-August. Typhoons often occur during May-November and the prevailing northeasterly winds occur during September-March, at this monsoon period the hydrological regime is affected by strong dry winds from land to seaward, leading to a weak ocean swell and a relatively clean water environment. One typhoon, MAGGIE, occurred in July of 1999 and two typhoons, KAI-TAK and BILIS, occurred in July and August 2000, respectively.

\subsection{Estimation of algal biomass}

Four line transects perpendicular to the shore were set at 100-m intervals and sampling stations on each line transect were set at $0,25,50,75$ and $100 \mathrm{~m}$ away from the average high tide mark towards the low tide mark (i.e. 0-5-m water depth (MHWS) in a seaward gradient). Because almost no macroalgae were found at the highest tidal region (i.e. 0-m sampling station), the data of $0-\mathrm{m}$ sampling station were not included in this study. There were 16 replicates with each sampling stations. At each sampling station, algal $\%$ cover was estimated monthly using a $50 \times 50-\mathrm{cm}$ quadrat and thalli within the quadrats were collected and dried at $80{ }^{\circ} \mathrm{C}$ for the determination of areal biomass.

\subsection{Determination of seawater nutrient concentra- tions and algal tissue nutrient contents}

Near-bottom (20 $\mathrm{cm}$ above the bottom) seawater samples were collected at each sampling station and stored at $4{ }^{\circ} \mathrm{C}$ for transportation to the laboratory. Then, seawater was filtered through Whatman $\mathrm{CF} / \mathrm{G}$ paper $(0.45 \mu \mathrm{m})$ and immediately frozen in $\mathrm{a}-70{ }^{\circ} \mathrm{C}$ freezer until analysis. Before nutrient determination, frozen samples were thawed on ice in the dark. The determination of dissolved inorganic phosphorus (SRP) was modified from the method of Murphy and Riley (1962). Colour reagent was prepared by mixing $1 \mathrm{ml}$ of $3 \%$ ammonium molybdate solution and $0.75 \mathrm{ml}$ of $5 \mathrm{~N} \mathrm{H}_{2} \mathrm{SO}_{4}$ and after $10 \mathrm{~min}$ of incubation at room temperature, $0.9 \mathrm{ml}$ of $1 \mathrm{M}$ ascorbic acid (freshly prepared) and $0.08 \mathrm{ml}$ of $2 \%$ potassium antimonyl-tartrate were added and held at room temperature for a further $10 \mathrm{~min}$. Then, $50 \mu 1$ of colour reagent was added in $0.5 \mathrm{ml}$ of seawater and after $10 \mathrm{~min}$ of incubation at room temperature, the absorbance was read at $882 \mathrm{~nm}$ within $15 \mathrm{~min}$ by a Hitach spectrophotometer (model U-2000, Hitachi, Tokyo, Japan). The detection limit of SRP concentration was $0.02 \mu \mathrm{M}$. Seawater $\mathrm{NO}_{2}^{-}$and $\mathrm{NO}_{3}^{-}$ concentrations were determined according to Strickland and Parsons (1972) and $\mathrm{NH}_{4}^{+}$concentrations were determined according to Parsons et al. (1984). The detection limits for seawater $\mathrm{NO}_{2}^{-}, \mathrm{NO}_{3}^{-}$and $\mathrm{NH}_{4}^{+}$concentrations were $0.2,0.2$ and $0.3 \mu \mathrm{M}$, respectively. The $\mathrm{NO}_{3}^{-}, \mathrm{NO}_{2}^{-}$, and $\mathrm{NH}_{4}^{+}$concentrations were summed as the concentration of dissolved inorganic nitrogen (DIN).

For the determination of tissue $\mathrm{N}$ and $\mathrm{P}$ contents, dried thalli were ground to powder and powder sample of $5 \mathrm{mg}$ dry weight (d. wt.) was put in 10$\mathrm{ml}$ test tube, then $0.05 \mathrm{~g}$ of catalyst $\mathrm{A}(\mathrm{HgO} /$ $\left.\mathrm{K}_{2} \mathrm{SO}_{4}=1: 20(\mathrm{w} / \mathrm{w})\right)$ and $0.025 \mathrm{~g}$ of catalyst $\mathrm{B}$ $\left(\mathrm{Na}_{2} \mathrm{~S}_{2} \mathrm{O}_{3}\right)$ were added. After the addition of $1 \mathrm{ml}$ conc. $\mathrm{H}_{2} \mathrm{SO}_{4}$ containing $5 \%$ salicylic acid, thallus samples together with catalysts were digested at high temperature $\left(400{ }^{\circ} \mathrm{C}\right)$. When solution became clear, the digested samples were cooled at room temperature and made up to $5 \mathrm{ml}$ with distilled $\mathrm{H}_{2} \mathrm{O}$. Tissue $\mathrm{N}$ and $\mathrm{P}$ contents were detected by colour development of $\mathrm{H}_{2} \mathrm{SO}_{4}$-digested samples in the dark according to Smith (1980) (phenol-nitroprusside method) and Lanzetta et al. (1979), respectively. Tissue C contents were determined by titrimetric dichromate redox method (Tiessen and Moir, 1993). Algal tissue C and $\mathrm{N}$ contents were confirmed by elemental analyzer analysis (Perkin-Elmer 2400 (II) CHN analyzer). Algal tissue nutrient contents were expressed as the percentage $(\%)$ of $\mathrm{g} d$. wt.

\subsection{Determination of APA}

Algal APA was determined by modification of the method described by Lapointe et al. (1992). Apical thalli (0.48-0.58 g wet weight) were put in a capped 
Pyrex test tube $(25 \mathrm{ml})$ containing $5 \mathrm{~mL}$ of ambient seawater with $1 \mathrm{mM} p$-NPP (freshly prepared in distilled $\mathrm{H}_{2} \mathrm{O}$ ). To determine the interference of algareleased materials and auto-degraded $p$-NPP, two sets of controls were done. First set was the algal background by the incubation of algal materials without $p$ NPP (Sigma, USA). Second set was the seawater background carried out in two test tubes without algal materials: one was terminated by the addition of $1 \mathrm{M}$ $\mathrm{KOH}$ before incubation and the other was terminated after incubation, the net absorbance value between the above two tubes was the seawater background. All tubes were capped and immersed in waters for in situ incubation. After $1 \mathrm{~h}, 1 \mathrm{ml}$ of seawater was transferred to $1.5 \mathrm{ml}$ plastic micro-centrifugation tube and $250 \mu \mathrm{l}$ of $1 \mathrm{M} \mathrm{KOH}$ was added to terminate the reaction. Then, these tubes and algal materials were kept on ice in dark and then transferred to laboratory within $3 \mathrm{~h}$. After centrifugation at $15,000 \times g$ for $10 \mathrm{~min}$, the absorbance of supernatant was determined at $405 \mathrm{~nm}$. Algal samples were oven-dried at $80{ }^{\circ} \mathrm{C}$ to obtain algal dry weight. Average seawater background and algal background were obtained from three replicates. The obtained $A_{405}$ value of algal sample minus both average seawater $A_{405}$ values and average algal background $A_{405}$ values was converted to enzymatic activity (nmol $p$-NP released $\mathrm{h}^{-1} \mathrm{~g}^{-1} \mathrm{~d}$. wt.) by molar extinction coefficient of $p$-NP, $4.6 \times 10^{3} \mathrm{M}^{-1} \mathrm{~cm}^{-1}$.

\subsection{Estimation of critical and subsistence nutrient contents and growth temperature ranges}

A continuous-flow culture was used for the estimation of the critical and subsistence nutrient contents and also the growth temperature ranges and optima. Apical thalli were sampled in August 2003 and then incubated for 7 days in a 60-1 outdoor polyethylene tank containing 501 seawater aerated by air for recovery of wounding. Healthy thalli of $1 \mathrm{~g}$ wet weight (w. wt.) were cultured in a 1000-ml glass culture flask fitted with a tube for aeration in a flow rate of $20 \mathrm{ml} \mathrm{min}-1$ and two tubes for inflowing and outflowing culture seawater, which was pumped from a 60-1 polyethylene tank (nutrient tank) to the culture flask in the speed of $5 \mathrm{ml} \mathrm{min}{ }^{-1}$ with a peristaltic pump. Seawater was collected from Nanwan Bay in $4-5-\mathrm{m}$ depth and $20 \mathrm{~km}$ offshore to insure DIN $<0.1$ $\mu \mathrm{M}$ and SRP $<0.01 \mu \mathrm{M}$. After collection, seawater was immediately filtered through $5-\mu \mathrm{m}$ filter papers and stored at $4{ }^{\circ} \mathrm{C}$ in the dark before use. Seawater in the nutrient tank was changed every day and the flasks were shaded to obtain approximately $60 \%$ of full sun to mimic the light levels $\left(250-830 \mu \mathrm{E} \mathrm{m} \mathrm{m}^{-2} \mathrm{~s}^{-1}\right.$ between 8:00 am and 4:00 pm determined during August-September 1999) on the surface of these two rhodophytes in the field. Six flasks were linked to a nutrient tank and five replicate flasks were randomly sampled from a nutrient tank and their averaged value was the value of a nutrient tank. In this study, three replicate nutrient tanks were used for each nutrient or temperature treatment and the daily specific growth rate and algal tissue nutrient contents determined in the outdoor culture experiments were mean \pm S.E.M. $(n=3)$.

For the determination of critical and subsistence nutrient levels, the water temperatures of nutrient tanks were maintained in a range of $24-26{ }^{\circ} \mathrm{C}$ by cooler and heater. According to monthly surveys of seawater nutrient concentrations during 1996-1998 at the present study site that the average $\mathrm{NH}_{4}^{+}, \mathrm{NO}_{3}^{-}$, and $\mathrm{PO}_{4}^{3-}$ concentrations were $3.04,6.58$ and 0.43 $\mu \mathrm{M}$, respectively, and to simulate seawater nutrient status at the present study site, $\mathrm{NO}_{3}^{-}$and $\mathrm{NH}_{4}^{+}$were applied together as nitrogen source and $\mathrm{PO}_{4}^{3-}$ was used as SRP source that the levels of $\mathrm{NO}_{3}^{-} / \mathrm{NH}_{4}^{+}$/ $\mathrm{PO}_{4}^{3-}$ for the determination of critical nutrient contents were set at 0:0:0, 0.4:0.2:0.03, 0.8:0.4:0.06, $1: 0.5: 0.075,1.3: 0.67: 0.1,1.6: 0.8: 0.12,2: 1: 0.15$, $4: 2: 0.3,8: 4: 0.6,16: 8: 0.6$, and 24:12:1.8 $(\mu \mathrm{M})$ for $L$. papillosa, and $0: 0: 0,1: 0.5: 0.075,1.6: 0.8: 0.12$, $2: 1: 0.15,3: 1: 0.225,4: 2: 0.3,6: 3: 0.45,10: 5: 0.75$, $16: 8: 1.2,30: 15: 2.25,40: 20: 3,60: 30: 4.5$, and 90:30:6 $(\mu \mathrm{M})$ for $G$. coronopifolia. $\mathrm{NO}_{2}^{-}$was not used due to trace $\mathrm{NO}_{2}^{-}$amount detected during 19961998 (the average concentration was $0.03 \pm 0.05 \mu \mathrm{M}$ ). Although there have several reports that $\mathrm{NH}_{4}^{+}$reduces $\mathrm{NO}_{3}^{-}$uptake of several macroalgae (Haines and Wheeler, 1978; D'Elia and DeBoer, 1978; Thomas and Harrison, 1987), and it has been recently shown that $\mathrm{NO}_{3}^{-}$uptake was suppressed by $38 \%$ in the presence of $\mathrm{NH}_{4}^{+}>5 \mu \mathrm{M}$ in the rhodophyte Gracilaria (Smit, 2002), the combined application of $\mathrm{NH}_{4}^{+}$and $\mathrm{NO}_{3}^{-}$was to estimate the responses to seawater nutrient compositions at the present study site. Nutrient-enriched seawater in the nutrient tank was changed every day. To check the nutrient concen- 
trations in the flasks, the seawater nutrient concentrations in the flasks were selectively determined after 1 day of culture in "1:0.5:0.075 $\left(\mathrm{NO}_{3}^{-} / \mathrm{NH}_{4}^{+} / \mathrm{PO}_{4}^{3-}\right)$ $\mu \mathrm{M}$ ", "4:2:0.3 $\mu \mathrm{M}$ ", "16:8:1.2 $\mu \mathrm{M}$ ", and 60:30:4.5, treatments along the culture period. Average concentrations of $\mathrm{NO}_{3}^{-}, \mathrm{NH}_{4}^{+}$, and $\mathrm{PO}_{4}^{3-}$ were $0.98 \pm 0.06$ (means \pm S.D., $n=36$ ), $0.49 \pm 0.03$, and $0.07 \pm 0.005$ $\mu \mathrm{M}$ for "1:0.51:0.075 $\left(\mathrm{NO}_{3}^{-} / \mathrm{NH}_{4}^{+} / \mathrm{PO}_{4}^{3-}\right) \mu \mathrm{M}$ " treatment, 3.96 $\pm 0.09,2.06 \pm 0.03$, and $0.31 \pm 0.04 \mu \mathrm{M}$ $(n=36)$ for " $4: 2: 0.3 \mu \mathrm{M}$ " treatment, $15.73 \pm 0.11$, $8.12 \pm 0.08, \quad 1.18 \pm 0.03 \mu \mathrm{M}(n=36)$ for " $16: 8: 1.2$ $\mu \mathrm{M}$ " treatment, and $59.33 \pm 0.96,31.26 \pm 0.29$, and $4.36 \pm 0.11 \mu \mathrm{M}(n=18)$ for " $60: 30: 4.5 \mu \mathrm{M}$ ” treatment. These data indicate that the nutrient concentrations remained almost unchanged after culture. Algal wet weight was determined at the start and after 16 days of incubation for the calculation of daily specific growth rate $\left(\%\right.$ day $\left.^{-1}\right):\left(W_{16}-W_{0}\right) / W_{0} / 16 \times 100 \%$ $\left(W_{0}=\right.$ wet weight at day $0, W_{16}=$ wet weight at day 16). Then, sampled thalli were dried at $80{ }^{\circ} \mathrm{C}$ and ground to powder for tissue nutrient content analysis. Tissue nutrient contents in algae whose specific growth rate is just before maximum are critical contents (Hanisak, 1979). Subsistence contents were determined by incubation of algae in ambient seawater without nutrient pulse and tissue $\mathrm{N}$ and $\mathrm{P}$ contents in algae whose growth rate is zero are subsistence N and P levels (Fujita et al., 1989).

For the determination of growth temperature ranges and optimum, seven temperature levels (15, $20,22.5,25,27.5,30$ and $\left.35^{\circ} \mathrm{C}\right)\left( \pm 1.0{ }^{\circ} \mathrm{C}\right)$ were set in different nutrient tanks and algal thalli were cultured in 1000-ml glass flasks for 16 days in seawater enriched with or without nutrients $\left(\mathrm{NO}_{3}^{-} /\right.$ $\left.\mathrm{NH}_{4}^{+} / \mathrm{PO}_{4}^{3-}=5: 2.5: 0.375(\mu \mathrm{M})\right)$. For each temperature treatment, six replicate flasks were supplied by a nutrient tank and five flasks were randomly sampled from used and the daily specific growth rate was determined after 16 days as the following equation: $\%$ day $^{-1}=\left(W_{16}-W_{0}\right) / W_{0} / 16 \times 100 \%\left(W_{0}=\right.$ wet weight at day $0, W_{16}=$ wet weight at day 16). During the 16-day culture period, daily seawater samples in the flasks were taken for nutrient concentration determination. The average concentrations of $\mathrm{NO}_{3}^{-}, \mathrm{NH}_{4}^{+}$, and $\mathrm{PO}_{4}^{3-}$ for 5:2.5:0.375 $\mu \mathrm{M}$ treatment were $4.95 \pm 0.21$, $2.43 \pm 0.23$, and $0.377 \pm 0.009 \mu \mathrm{M}$ (means \pm S.D., $n=672$ ), respectively. Thus, seawater nutrient concentrations did not change after 1-day culture. The growth temperature range was defined on the basis of positive specific growth rate.

\subsection{Statistical analysis}

SAS program (SAS, NC, USA) was used to analyze the field and experimental data. One-way analysis of variance (ANOVA) was used to compare means of areal dry weight biomass, seawater nutrient concentrations, algal tissue nutrient contents and algal APA with a factor of time. Two-way ANOVA was used for temperature experiments with factors of temperature and nutrient. Tukey's test was used for multiple comparisons among means from significant ANOVA tests $(P<0.05)$ (Day and Quinn, 1989). Homogeneity of variance was determined using the $F_{\max }$ test (Sokal and Rohlf, 1981).

The stepwise regression analysis was used to determine the best multiple regression model to correlate the areal dry weight biomass of both $L$. papillosa and G. coronopifolia with environmental parameters. Parameters entered into the model for each sampling time were seawater temperature, surface irradiance, seawater $\mathrm{DIN}, \mathrm{NO}_{2}^{-}, \mathrm{NO}_{3}^{-}$and $\mathrm{NH}_{4}^{+}$concentrations, and seawater SRP concentrations. To normalize data, the areal dry weight biomass of $L$. papillosa and seawater $\mathrm{NO}_{2}^{-}$concenconcentrations, seawater $\mathrm{NH}_{4}^{+}$concentrations were double root (i.e. 4th root)-transformed (expressed as $\sqrt{ }$ ), and seawater SRP concentrations were roottransformed (expressed as $\sqrt{ }$ ). Significance was set at the 0.05 level.

\section{Results}

\subsection{Climate data and seawater nutrient concentrations}

The climate data of Hengchuan Peninsula during 1999-2000 were obtained from the Central Weather Bureau of Taiwan of Republic of China. Monthly mean air temperature showed significant temporal variations $(P=0.0001)$ that were high in MayOctober and low in December-April, and seawater temperatures showed a similar trend; mean air and seawater temperatures were 25.14 and $24.97{ }^{\circ} \mathrm{C}$, respectively (Fig. 2). During the survey, monthly 


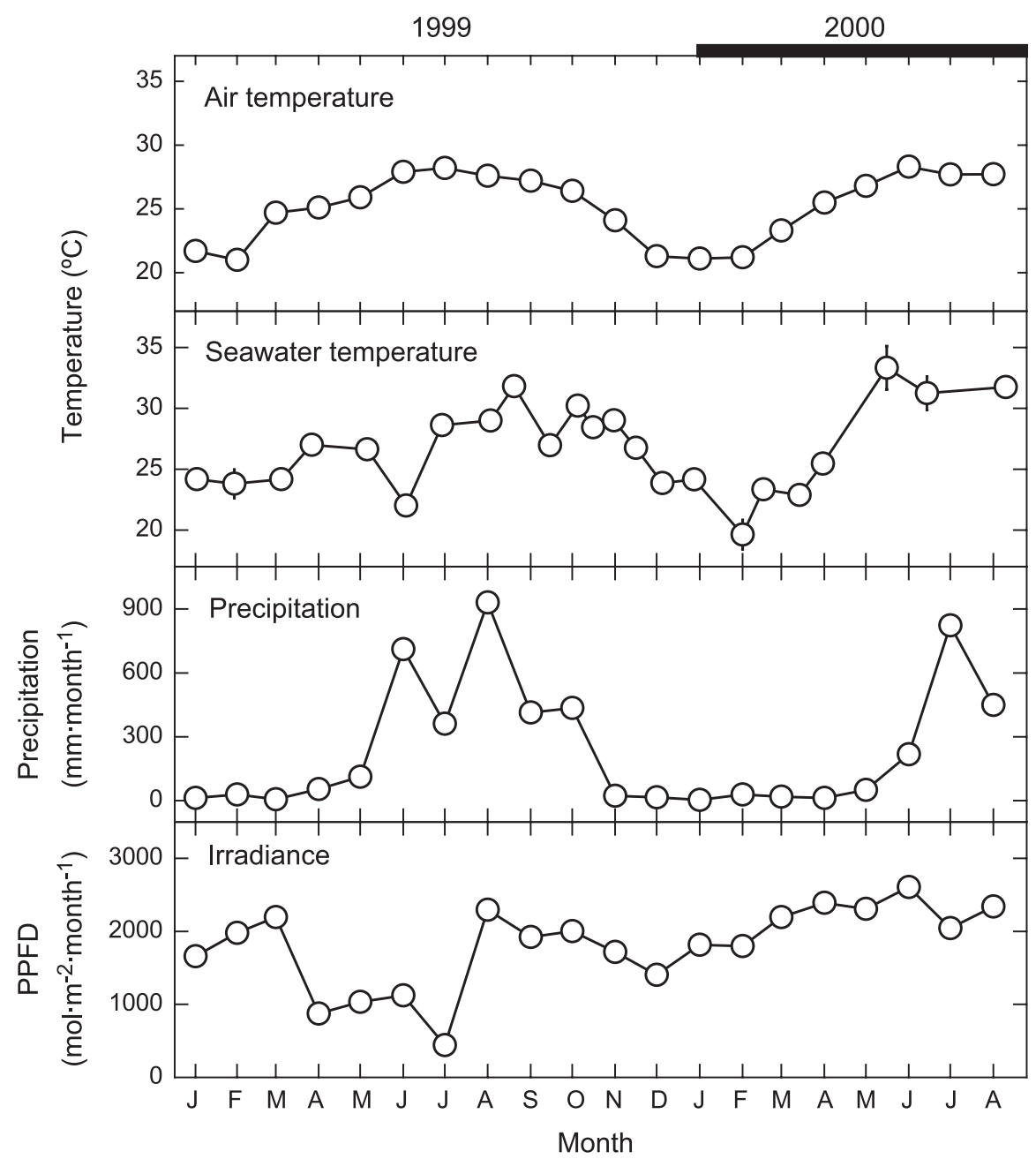

Fig. 2. Mean monthly air and seawater temperatures, monthly cumulative precipitation, and monthly cumulative irradiance during $1999-2000$.

cumulative photosynthetic photon flux density (PPFD) had a range from 1403 to $2605 \mathrm{~mol} \mathrm{~m}^{-2}$ month $^{-1}$, except 441-1121 mol m month $^{-1}$ in April-June 1999 (Fig. 2). Monthly cumulative precipitation was high during May-October (Fig. 2). This suggests that the climate of Hengchuan Peninsula can be grouped into the warmer and wet months (May-October) and the cooler and dry months (November-April).

Seawater nutrient concentrations (DIN, $\mathrm{NO}_{3}^{-}$, $\mathrm{NO}_{2}^{-}, \mathrm{NH}_{4}^{+}$, and SRP) were extremely high and varied seasonally during the survey $(P=0.0001)$ (Fig. 3). DIN concentrations, ranging from 0.07 to $18.80 \mu \mathrm{M}$, peaked in July and December 1999 and mid April 2000, respectively. $\mathrm{NO}_{3}^{-}$concentrations, ranging from $0-12.33 \mu \mathrm{M}$, increased in July 1999 and in April-May 2000, $\mathrm{NO}_{2}^{-}$concentrations, ranging from 0 to $1.33 \mu \mathrm{M}$, increased in January and April 2000, and $\mathrm{NH}_{4}^{+}$concentrations, ranging from 0 to $12.45 \mu \mathrm{M}$, increased in November 1999January 2000. Mean DIN, $\mathrm{NO}_{3}^{-}, \mathrm{NO}_{2}^{-}$and $\mathrm{NH}_{4}^{+}$ concentrations during the survey were $6.40 \pm 5.01$, $4.10 \pm 3.04,0.22 \pm 0.34$ and $2.08 \pm 3.59 \mu \mathrm{M}$, respectively. SRP concentrations, ranging from 0 to 3.47 $\mu \mathrm{M}$, peaked in July 2000 and had the mean concentration was $0.71 \pm 0.23 \mu \mathrm{M}$ during the survey. DIN/SRP molar ratio increased in December 1999May 2000. 


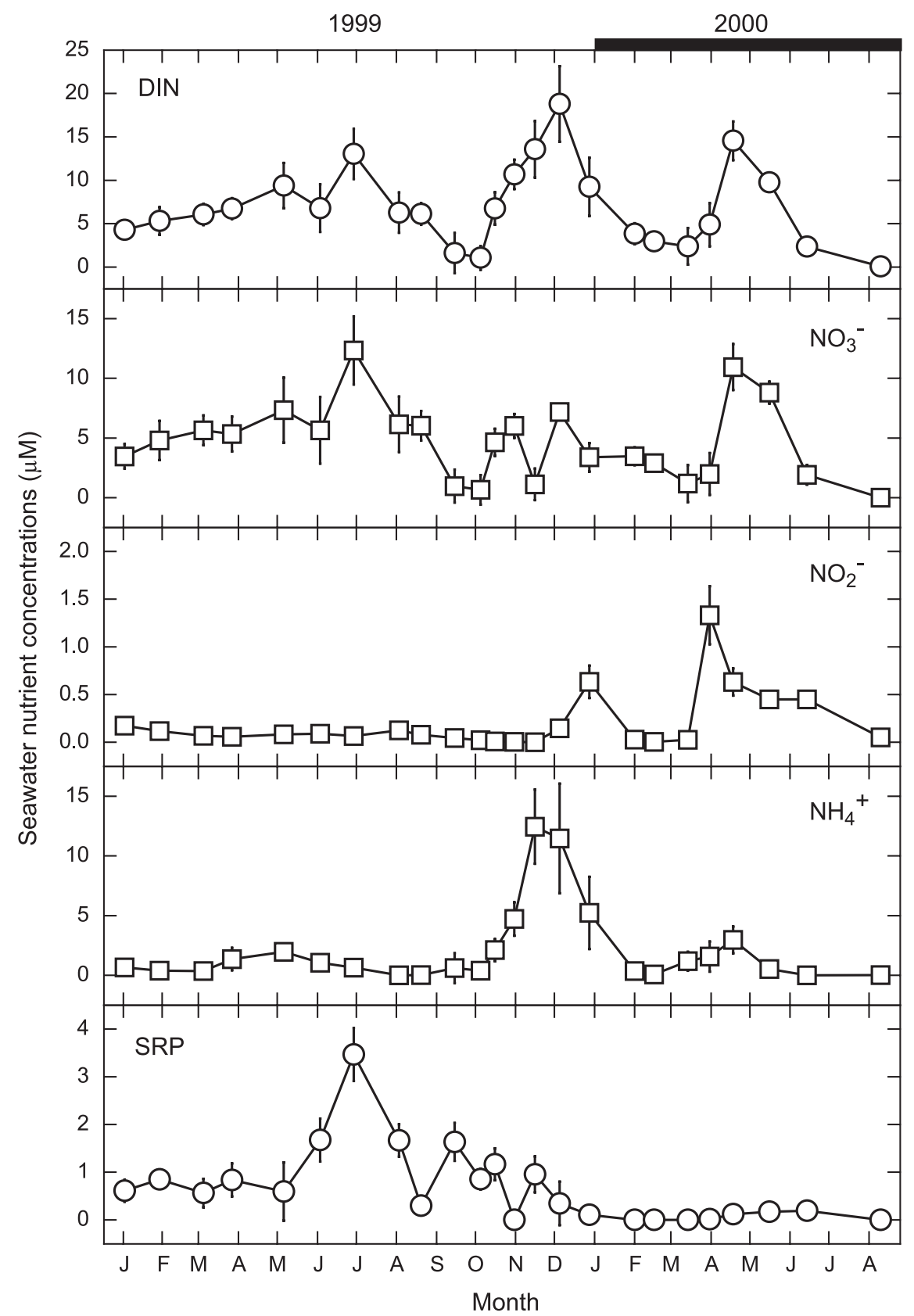

Fig. 3. Seasonal variations in seawater nutrient concentrations during 1999-2000. Data are means ( $n=16)$ with $95 \%$ confidence limits.

\subsection{Algal biomass and stepwise multiple regression analysis}

During the survey, the percentage total line biotic cover was high in March (72.37-82.50\%) and low in
July (47.43-51.23\%). Macroalgae were the dominant component that \%cover was $59.08-67.26 \%$ in March and $34.19-36.48 \%$ in July; Padina spp., Gracilaria spp., Laurencia spp., Halimeda spp. and Sargassum spp. were the dominant species. Gracilaria spp. and 
Laurencia spp. were widely distributed at 25-, 50- and 75-m sampling stations. Coral cover ranged from $8.06 \%$ to $15.60 \%$; Favia spp. and Platygyra spp. were the dominant species mainly distributed at $75-$ and 100-m sampling stations. Low coral cover and high algal cover can be interpreted to indicate coral reef decline in southern Taiwan.

The areal dry weight biomass of both L. papillosa and $G$. coronopifolia varied seasonally according to species ( $P=0.0001$ ) (Fig. 4). The areal biomass of $L$. papillosa started to increase in August and reached the maximum in mid August-September following a significant decrease after mid November. G. coronopifolia was abundant year around except April-May; its areal biomass significantly decreased in May 1999 following an increase in August 1999-February 2000, and then again a decline in mid April-mid May 2000.

The multiple regression analysis was used to elucidate the relationship between environments (seawater temperature, irradiance, and seawater nutrient concentrations) and macroalgal biomass. The results indicated that seasonal variations in areal biomass of L. papillosa were positively correlated with seawater temperature but negatively correlated with seawater $\mathrm{NO}_{2}^{-}$and $\mathrm{NO}_{3}^{-}$concentrations: $\sqrt{ } \sqrt{ }$ (biomass $)=0.0895$ (seawater temperature)-0.8519 ( $\sqrt{ }$ (seawater $\mathrm{NO}_{2}^{-}$ concentration) $)-0.0773$ (seawater $\mathrm{NO}_{3}^{-}$concentration) (Table 1). The correlation coefficients ( $R$ value) for seawater temperature, $\sqrt{ } \sqrt{ }$ (seawater $\mathrm{NO}_{2}^{-}$concentration) and seawater $\mathrm{NO}_{3}^{-}$concentration were $0.2030,0.4932$ and 0.5411 , respectively. Seasonal variations in monthly cumulative irradiance and seawater DIN and SRP concentrations were not correlated with areal biomass of L. papillosa $(P>0.05)$. Areal biomass of $G$. coronopifolia was negatively correlated with seawater $\mathrm{NO}_{3}^{-}$concentrations: (biomass) $=15.1163-1.7718$ (seawater $\mathrm{NO}_{3}^{-}$concentration), and the correlation coefficient ( $R$ value) for $\mathrm{NO}_{3}^{-}$concentration was 0.1215 (Table 1). Seasonal variations in monthly cumulative irradiance and seawater DIN, $\mathrm{NO}_{2}^{-}$, and SRP concentrations were not correlated with $G$. coronopifolia biomass $(P>0.05)$.

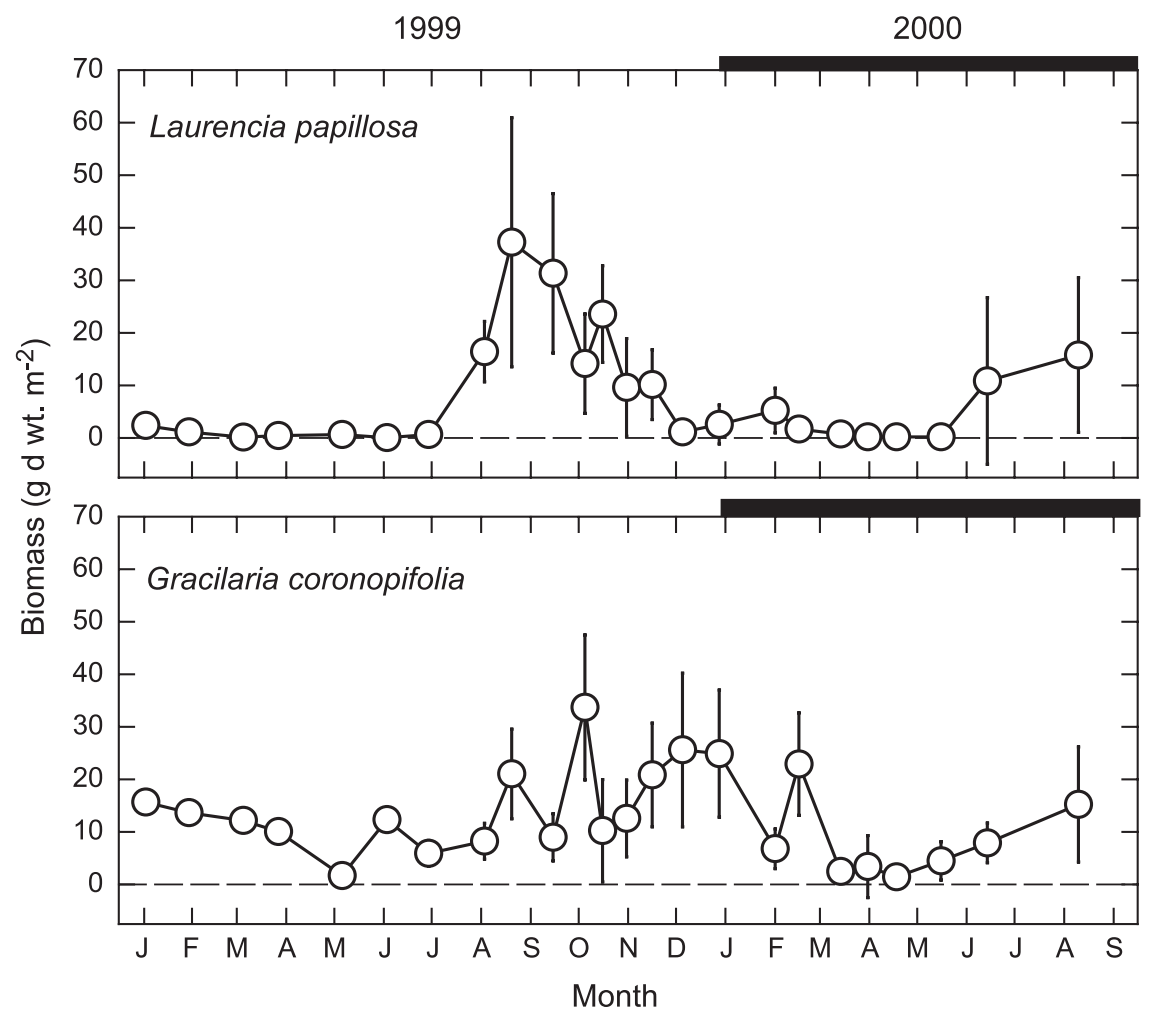

Fig. 4. Seasonal variations in areal biomass of $L$. papillosa and G. coronopifolia. Data are means $(n=16)$ with $95 \%$ confidence limits. 
Table 1

Results of stepwise multiple regression analysis for L. papillosa and G. coronopifolia areal dry weight biomass

\begin{tabular}{lccccc}
\hline Variable & Coefficient & S.E. & $F$ & $P$ & $R$ \\
\hline $\begin{array}{l}\text { Dependent variable: } \\
\text { Le papillosa }\end{array}$ & & & & \\
$\begin{array}{l}\text { Seawater temperature } \\
\text { Seawater } \mathrm{NO}_{2}^{-}\end{array}$ & 0.0895 & 0.0265 & 11.39 & 0.0030 & 0.2030 \\
$\quad \begin{array}{c}\text { concentration } \\
\text { a }\end{array}$ & -0.8519 & 0.4045 & 4.4 & 0.0480 & 0.4392 \\
$\begin{array}{l}\text { Seawater } \mathrm{NO}_{3}^{-} \\
\quad \text { concentration }\end{array}$ & -0.0773 & 0.0299 & 6.6 & 0.0177 & 0.5411 \\
& & & & &
\end{tabular}

Dependent variable: $G$. coronopifolia

\begin{tabular}{lrrrrr} 
Constant & 15.1163 & 3.0565 & 24.4 & 0.0001 & \\
$\begin{array}{l}\text { Seawater } \mathrm{NO}_{3}^{-} \\
\text {concentration }\end{array}$ & -1.7718 & 0.7129 & 6.1 & 0.0214 & 0.1215 \\
\hline
\end{tabular}

${ }^{\text {a }}$ Double root-transformed.

\subsection{Algal tissue nutrient contents}

Tissue nutrient contents and tissue $\mathrm{C} / \mathrm{N}, \mathrm{C} / \mathrm{P}$ and N/ $\mathrm{P}$ molar ratios of $L$. papillosa varied seasonally $(P=0.0001)$ (Fig. 5). Tissue $\mathrm{C}$ contents were low
(16.62-18.75\%) during April-July and high (19.5726.08\%) during August-March, tissue N contents were low $(0.74-1.72 \%)$ during February-June and high (1.16-3.87\%) during July-January, and tissue P contents were ranged from $0.03 \%$ to $0.04 \%$ during February-March that were relatively low as compared to $0.04-0.14 \%$ during May-February. Tissue $\mathrm{C} / \mathrm{N}$ molar ratios were high (18-30) during February-June and low (7-21) during July-January and in contrast, tissue N/P molar ratios were low (13-74) during February-June and high (33-240) during July-January. During the growing period (June-November), tissue C/P molar ratios were low (682-837) during the emergence of young plants (June-July 2001) and then increased to a peak in mid September 2001 following a sharp drop.

Tissue nutrient contents and tissue $\mathrm{C} / \mathrm{N}, \mathrm{C} / \mathrm{P}$ and N/ $\mathrm{P}$ molar ratios of $G$. coronopifolia also varied seasonally $(P=0.0001)$ (Fig. 6) Tissue $\mathrm{C}$ contents were low (16.8-25.6\%) during April-August and high
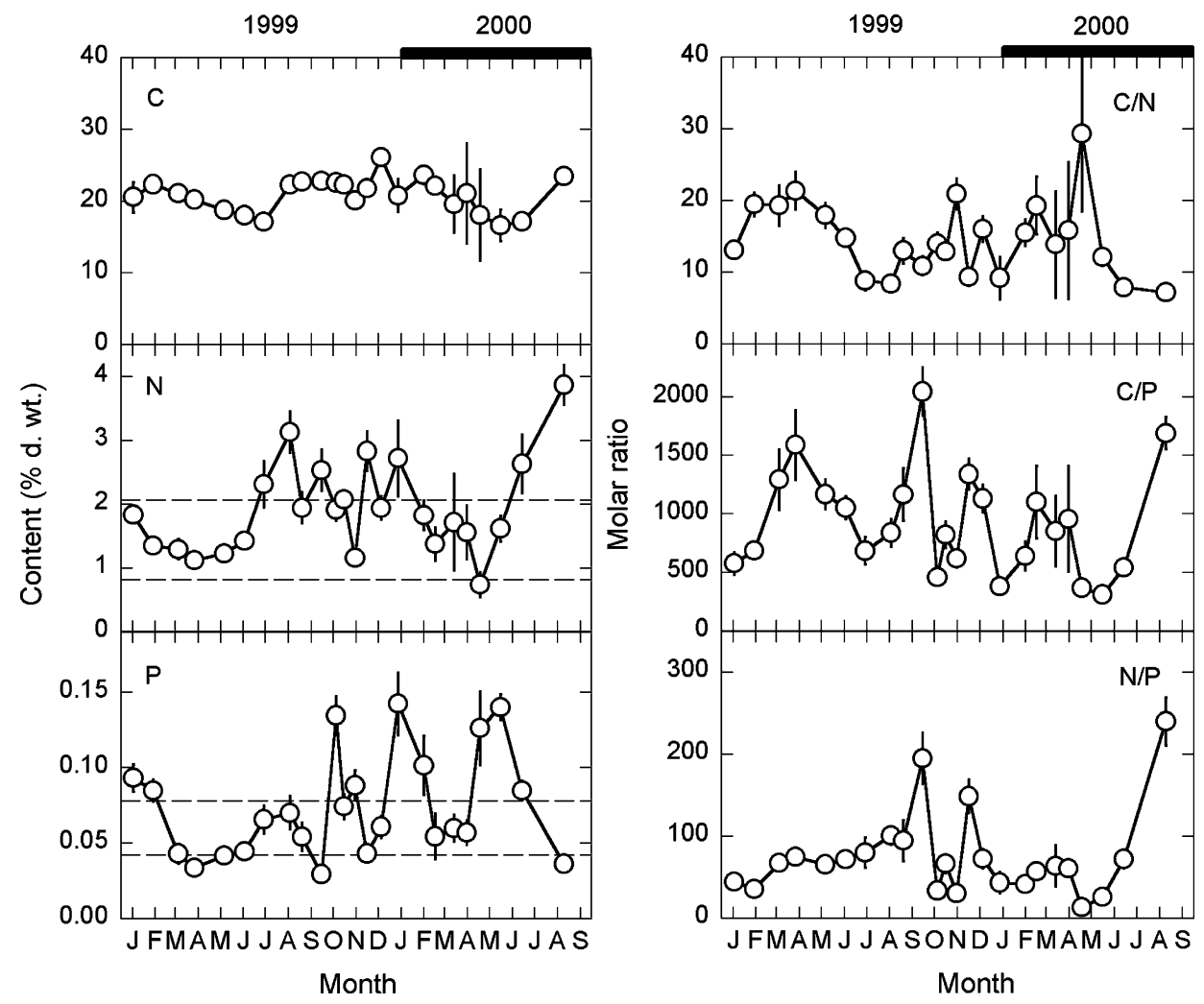

Fig. 5. Seasonal variations in tissue $\mathrm{C}, \mathrm{N}$ and $\mathrm{P}$ contents and $\mathrm{C} / \mathrm{N}, \mathrm{C} / \mathrm{P}$, and $\mathrm{N} / \mathrm{P}$ molar ratios in L. papillosa. Data are means ( $n=16)$ with 95\% confidence limits. The upper and lower dash lines indicate the critical and subsistence nutrient contents, respectively. 

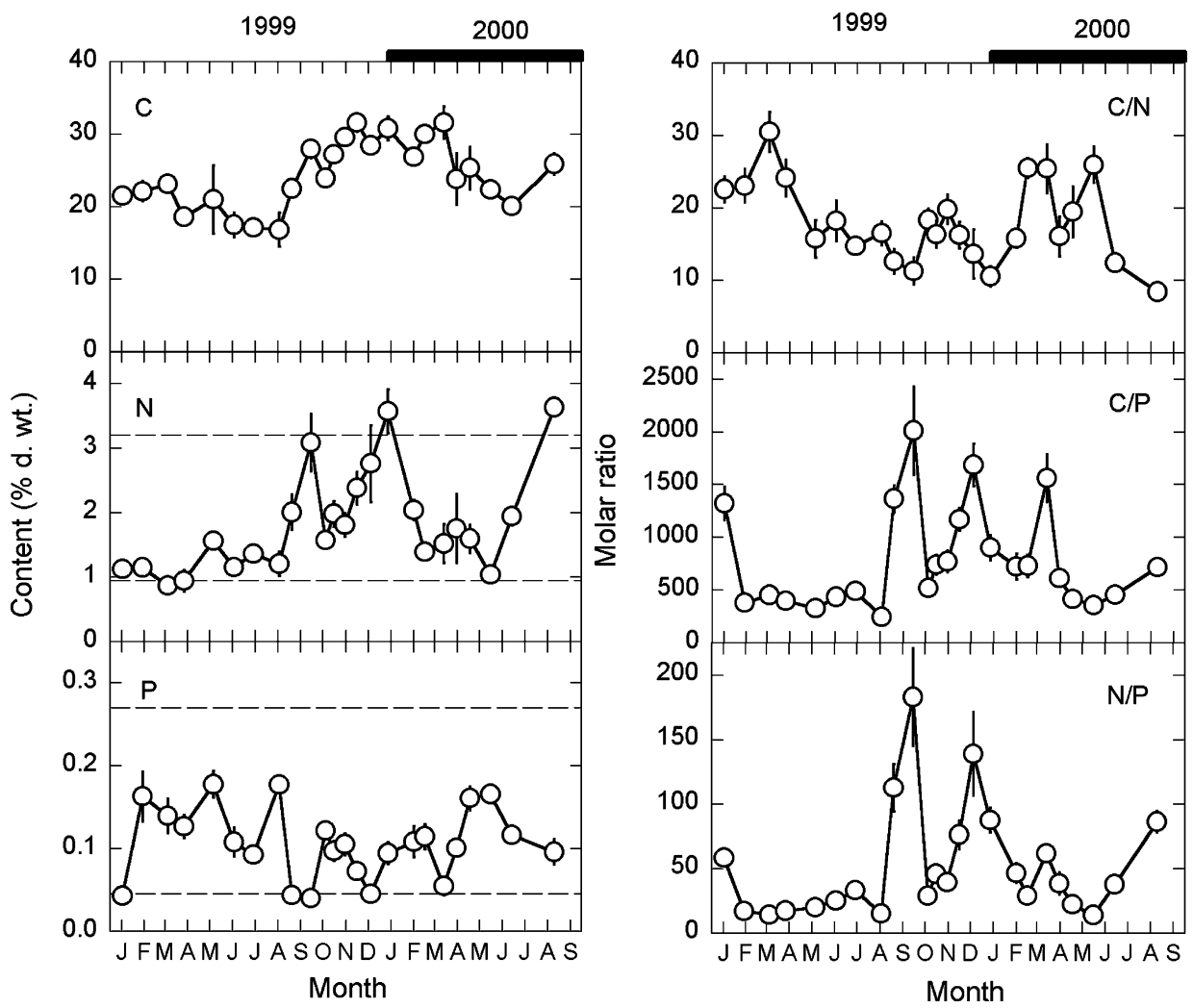

Fig. 6. Seasonal variations in tissue $\mathrm{C}, \mathrm{N}$ and $\mathrm{P}$ contents and $\mathrm{C} / \mathrm{N}, \mathrm{C} / \mathrm{P}$, and N/P molar ratios in G. coronopifolia. Data are means ( $n=16)$ with $95 \%$ confidence limits. The upper and lower dash lines indicate the critical and subsistence nutrient contents, respectively.

(26.9-31.6\%) during September-March. Tissue N contents were low $(0.86-1.94 \%)$ during FebruaryJuly and high (1.98-4.73\%) during SeptemberJanuary with peaks in mid September 1999, January 2000 and September 2000, respectively. In contrast, tissue $\mathrm{P}$ contents were low $(0.04-0.14 \%)$ during September-March and relatively high $(0.10-0.18 \%)$ during April-August. Tissue $\mathrm{C} / \mathrm{N}$ molar ratios peaked during mid February-May while tissue $\mathrm{C} / \mathrm{P}$ and N/P molar ratios peaked during September-March.

\subsection{Algal APA}

The APA of both L. papillosa and G. coronopifolia indicated significant seasonal variations (ANOVA, $P<0.05$ ) (Fig. 7). During the survey, the APA of $L$. papillosa increased in August 1999 and also in January-mid February 2000; the magnitude of APA increase in January-mid February 2000 was higher than that in August 1999. In comparison with $L$. papillosa, G. coronopifolia showed more frequent increase in APA during the survey. The APA of $G$. coronopifolia increased in February-April 1999, in October 1999, and in December 1999-January 2000; the magnitude of APA increase in December 1999January 2000 was relatively higher as comparing to those in both February-April 1999 and October 1999.

\subsection{Critical and subsistence nutrient contents}

Changes in daily specific growth rate and tissue $\mathrm{N}$ and $\mathrm{P}$ contents of L. papillosa in response to varying nutrient concentrations were determined to estimate the critical nutrient contents (Fig. 8A). As nutrient concentrations increased, daily specific growth rate increased and reached the maximum when $\mathrm{NO}_{3}^{-}$/ $\mathrm{NH}_{4}^{+} / \mathrm{PO}_{4}^{3-}$ were $\geq 2: 1: 0.15 \mu \mathrm{M}$. Tissue $\mathrm{N}$ and $\mathrm{P}$ contents increased as nutrient concentrations increased. Critical $\mathrm{N}$ and $\mathrm{P}$ contents were estimated as $2.06 \%$ and $0.078 \%$, respectively. 


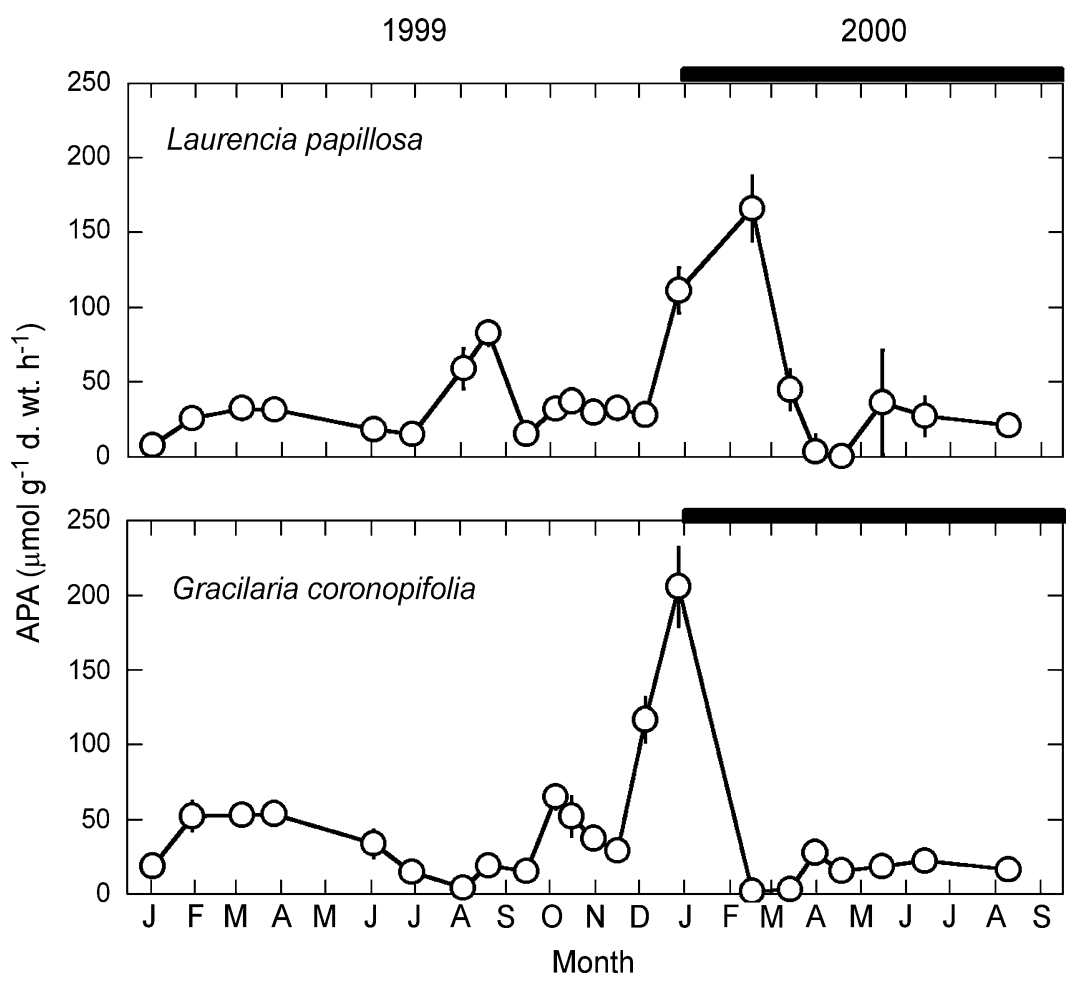

Fig. 7. Seasonal variations in APA of L. papillosa and G. coronopifolia. Data are means $(n=16)$ with $95 \%$ confidence limits.

The subsistence nutrient contents were estimated from the time-course changes in daily specific growth rate and tissue $\mathrm{N}$ and $\mathrm{P}$ contents of L. papillosa grown in seawater without nutrient enrichment (Fig. 8B). Daily specific growth rate decreased gradually after exposure to nutrient starvation and became negative after 20 days, and tissue $\mathrm{N}$ and $\mathrm{P}$ contents also decreased over time. The subsistence $\mathrm{N}$ and $\mathrm{P}$ contents were $0.81 \%$ and $0.042 \%$, respectively.

The changes of daily specific growth rate and tissue $\mathrm{N}$ and $\mathrm{P}$ contents in G. coronopifolia in response to varying nutrient concentrations showed that daily specific growth rate increased as $\mathrm{NO}_{3}^{-} / \mathrm{NH}_{4}^{+} /$ $\mathrm{PO}_{4}^{3-}$ increased from 0:0:0 to $16: 8: 1.2 \mu \mathrm{M}$ (Fig. 9A). Both tissue $\mathrm{N}$ and $\mathrm{P}$ contents increased as nutrient concentrations increased. The critical $\mathrm{N}$ and $\mathrm{P}$ contents of $G$. coronopifolia were $3.20 \%$ and $0.27 \%$, respectively. When exposed to nutrientstarved conditions, both daily specific growth rate and tissue $\mathrm{N}$ and $\mathrm{P}$ contents of $G$. coronopifolia decreased over time (Fig. 9B), and according to the comparison of tissue nutrient contents and daily specific growth rate, the subsistence $\mathrm{N}$ and $\mathrm{P}$ contents of $G$. coronopifolia were estimated as $0.94 \%$ and $0.045 \%$, respectively.

\subsection{Effects of temperature on daily specific growth rate}

The responses of algal growth to varying temperatures were carried out in continuous-flow seawater enriched with or without nutrients. The daily specific growth rates of both L. papillosa and G. coronopifolia were affected by temperature ( $P=0.0001)$ and nutrient enrichment $(P=0.0001)$, and the interaction between temperature and nutrient was significant $(P=0.0001$ for L. papillosa and $P=0.0001$ for G. coronopifolia) (Fig. 10).

When cultured in nutrient-enriched seawater, the daily specific growth rate of $L$. papillosa was positive in a range from 25 to $35^{\circ} \mathrm{C}$ and reached the maximum at $30-32.5{ }^{\circ} \mathrm{C}$, while that of $G$. coronopifolia was positive in a range from 15 to $35{ }^{\circ} \mathrm{C}$ and reached the maximum at $30{ }^{\circ} \mathrm{C}$. When incubated in seawater 
A

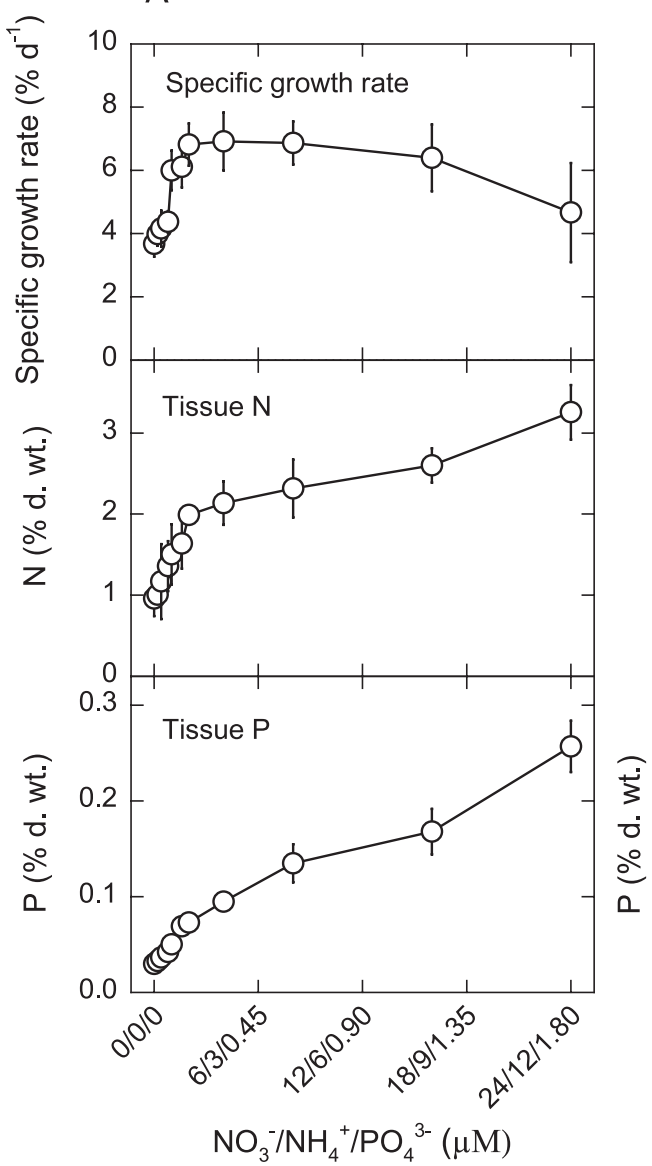

B

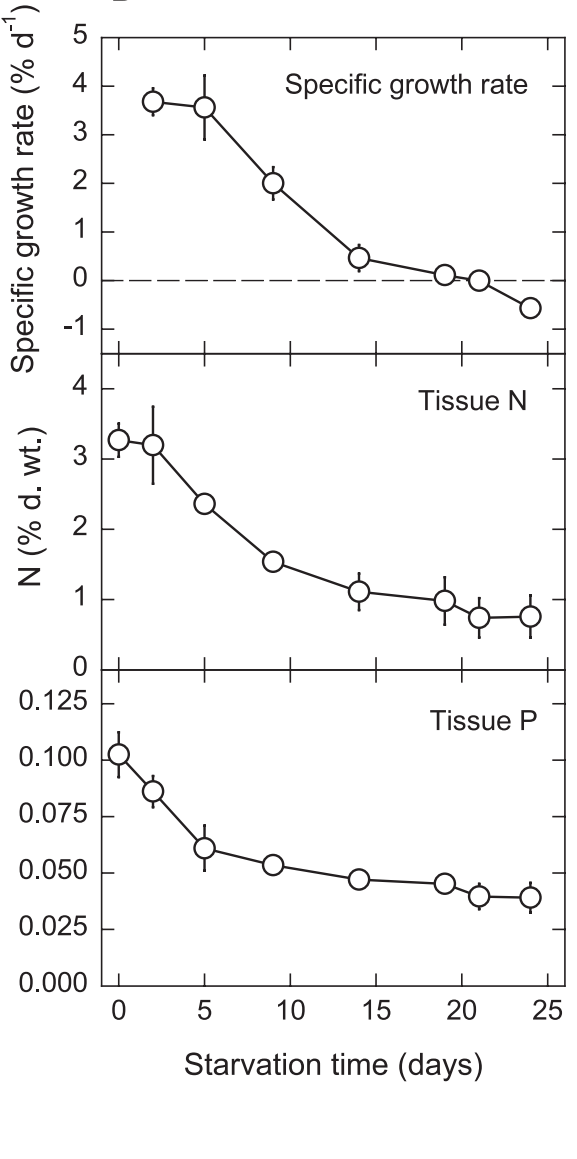

Fig. 8. Changes in daily specific growth rate and tissue $\mathrm{N}$ and $\mathrm{P}$ contents of $L$. papillosa in response to varying nutrient concentrations (A) or starvation treatment (B). Data are means $(n=3)$ with S.E.M.

without nutrient enrichment, the daily specific growth rate of L. papillosa was positive in a range from 25 to $35{ }^{\circ} \mathrm{C}$ and reached the maximum at $30-35{ }^{\circ} \mathrm{C}$, while that of G. coronopifolia was positive in a range from 20 to $35{ }^{\circ} \mathrm{C}$ and reached the maximum at $30{ }^{\circ} \mathrm{C}$.

\section{Discussion}

The seasonal patterns of two frondose rhodophytes $L$. papillosa and G. coronopifolia from a southern Taiwan coral reef were different that $L$. papillosa was a summer blooming alga abundant in AugustSeptember while G. coronopifolia appeared year round except April. The present results indicated that both seawater temperature and nutrient availability were important determinants influencing the seasonal growth of L. papillosa and nutrient availability was the main factor influencing the seasonal growth of $G$. coronopifolia. Our recent experiments have also provided multiple lines of evidence suggesting that nutrient enrichment and temperature limitation both play a role on the seasonal growth of Sargassum populations from the same coral reef of Nanwan Bay at Hengchuan Peninsula (Hwang et al., 2004).

All the results suggest a preference of L. papillosa for high temperatures. Based on the outdoor laboratory experiments, the occurrence of the maximum growth of L. papillosa at $30-32.5{ }^{\circ} \mathrm{C}$ gives a good explanation for the mass production of L. papillosa in the hot summer months that seawater temperatures ranged from 28.4 to $33.3{ }^{\circ} \mathrm{C}$ during July-September. 
A

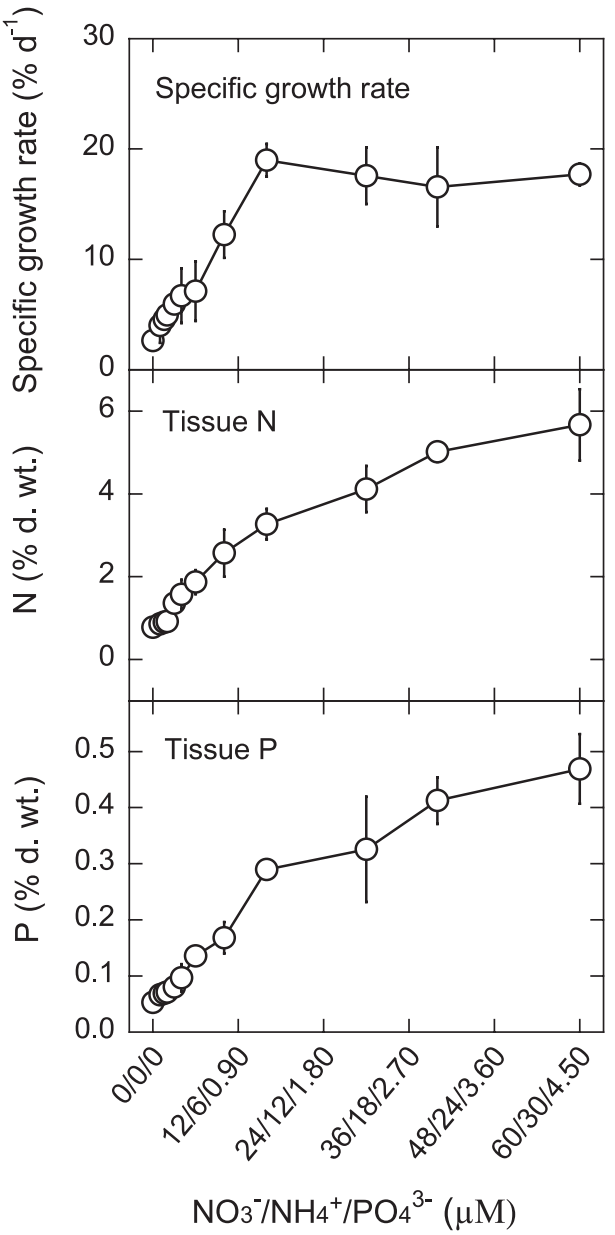

B

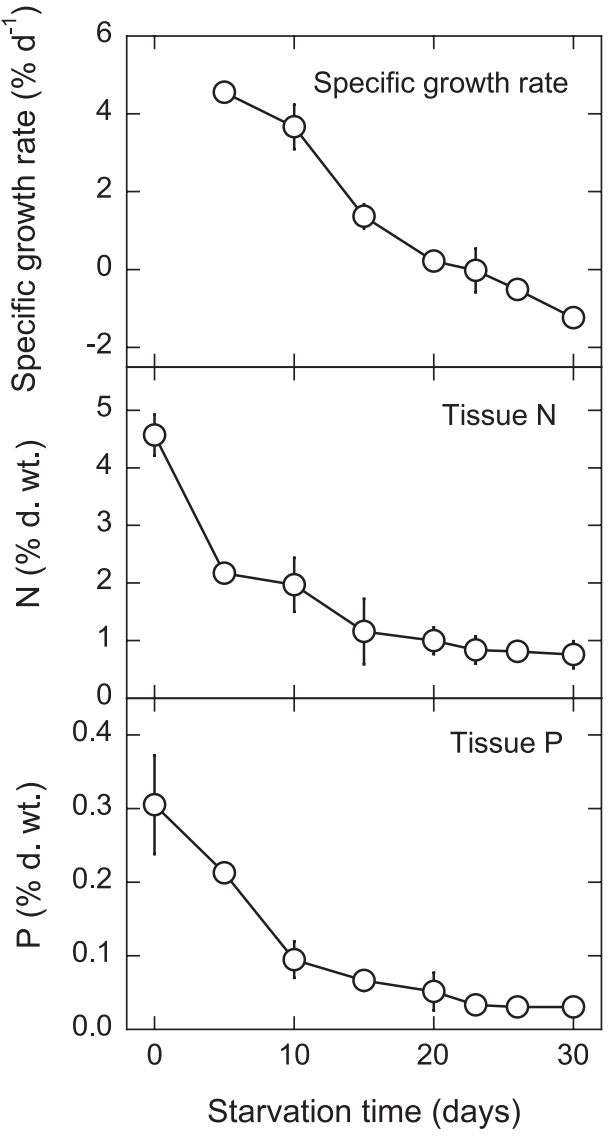

Fig. 9. Changes in daily specific growth rate and tissue $\mathrm{N}$ and $\mathrm{P}$ contents of $\mathrm{G}$. coronopifolia in response to varying nutrient concentrations (A) or starvation treatment (B). Data are means $(n=3)$ with S.E.M.

Because seawater temperatures during NovemberMarch were smaller than the lower growth temperature limit $\left(22.5{ }^{\circ} \mathrm{C}\right)$ of $L$. papillosa, it can be suggested that the low abundance of L. papillosa in the cold months was due to the limitation of growth by extreme low temperatures. The results of the stepwise multiple regression analysis of field data also showed that seawater temperature was positively correlated with $L$. papillosa biomass. It is not surprise for this red alga inhabited in the tropical waters of Taiwan that it tends to become more abundant in the hot summer months.

Seasonal variations in seawater temperature did not account for biomass variations of G. coronopifolia.
Because nutrient-enriched G. coronopifolia showed a more wider growth temperature range from 15 to 35 ${ }^{\circ} \mathrm{C}$ with the maximum at $30{ }^{\circ} \mathrm{C}$, its appearance year round except April in southern Taiwan can be expected. This was ascertained by the results of regression analysis that G. coronopifolia biomass did not correlate with seawater temperatures. The present data that seawater water temperatures were around $30{ }^{\circ} \mathrm{C}$ in the summer months also suggest that the growth of $G$. coronopifolia from southern Taiwan was not limited by high temperatures in the summer. Several studies have shown that the growth and physiological performance of Gracilaria from tropical waters is optimal at $25^{\circ} \mathrm{C}$. The best temperature for 

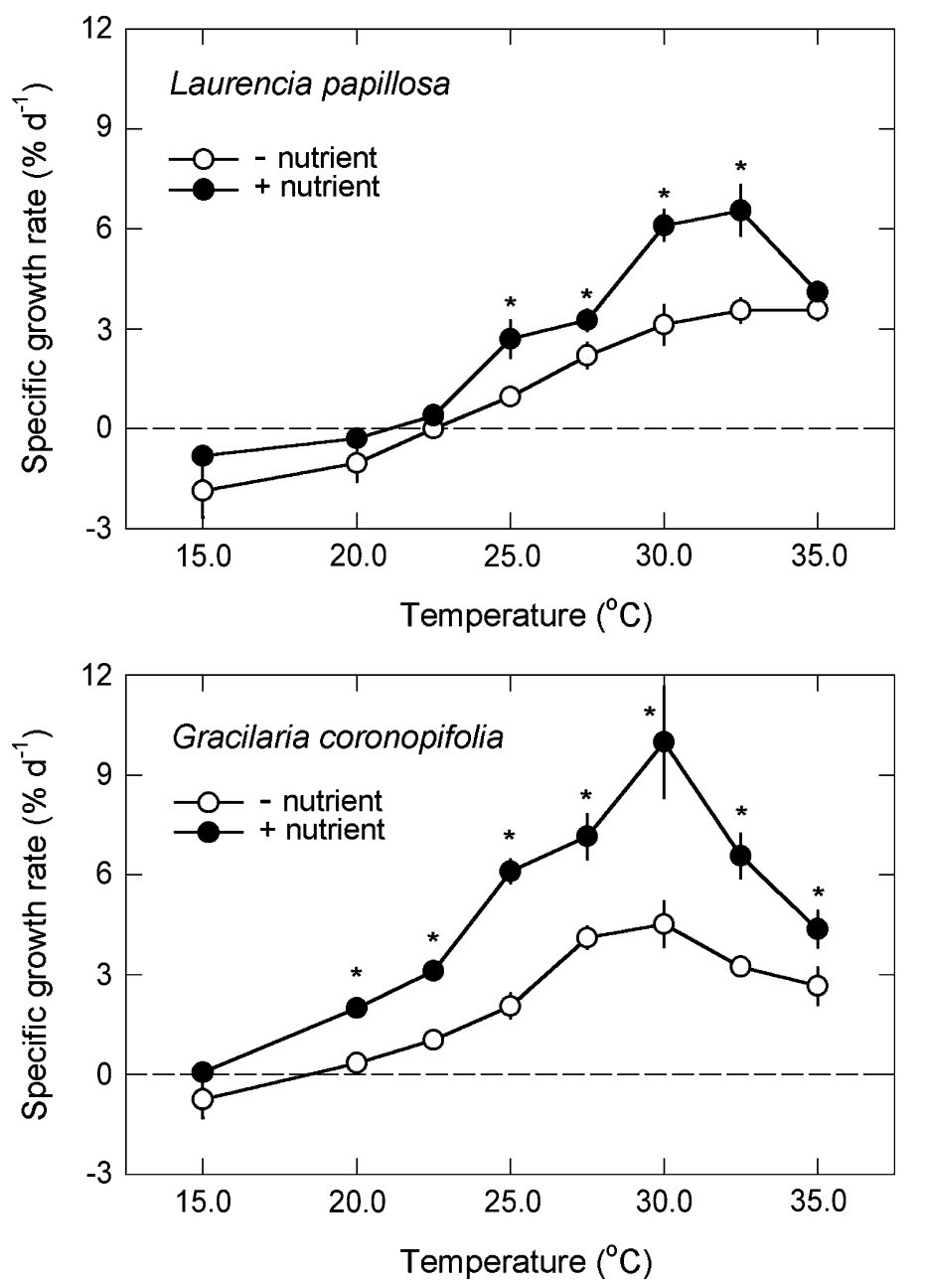

Fig. 10. Changes in daily specific growth rate of L. papillosa and G. coronopifolia in response to varying temperatures enriched with or without nutrients. Data are means $(n=3)$ with S.E.M. The symbol * indicates significant difference $(P<0.05, t$-test).

the growth of $G$. tikvahiae, a tropical alga from Florida, USA, was $25^{\circ} \mathrm{C}$ (Lapointe et al., 1984b). The data from flask culture showed that thalli of tetrasporophytes of $G$. verrucosa from Bacoor, Cavite, Philippines, had the maximal growth rate at $25{ }^{\circ} \mathrm{C}$ for apical segments and $30{ }^{\circ} \mathrm{C}$ for mid and basal segments (Hurtado-Ponce and Umezaki, 1987). The higher optimal temperature for southern Taiwan $G$. coronopifolia may be indicative of the adaptation to high temperature conditions. However, high temperatures in the hot summer months limit Gracilaria growth in the tropical waters. The field survey reported that G. cf. verrucosa in Shantou District, Guangdong, in mainland China disappeared from intertidal zones when water temperature $>30{ }^{\circ} \mathrm{C}$ (Wang et al., 1984). Other studies provide evidence that not only high temperature but also low temperature limit the growth of Gracilaria in the field. The survey carried out in Israel has shown that the growth of $G$. conferta declined in the winter months and reached the maximum in the summer months, mainly due to extreme seawater temperatures during these seasons: 13 and $31{ }^{\circ} \mathrm{C}$, respectively (Friedlander et al., 1987). The study of Lapointe et al. (1984a) suggests that temperature will become a limiting factor for G. tikvahiae sampled from shallow water in the Indian River of Florida, USA, when temperatures were $<15{ }^{\circ} \mathrm{C}$ during November and March in 
Florida, explaining their occurrence in summer months in north temperate waters. This study found that in southern Taiwan, seawater temperatures $(>20$ ${ }^{\circ} \mathrm{C}$ ) in November-March were near the lower growth temperature limit $\left(15{ }^{\circ} \mathrm{C}\right.$ for nutrient-enriched seawater and $20{ }^{\circ} \mathrm{C}$ for nutrient-unriched seawater) of $G$. coronopifolia, suggesting that the limitation of growth of $G$. coronopifolia in the cold months. However, $G$. coronopifolia still exhibited high biomass during November 1999-February 2000, suggesting that there are factors interacting with temperature and thus alleviates the restriction of growth in low temperatures. Here, we found that nutrient enrichment can shift the lower growth temperature limit in $G$. coronopifolia from $20{ }^{\circ} \mathrm{C}$ to $15{ }^{\circ} \mathrm{C}$, but did not alter the growth temperature range of L. papillosa. The results from the outdoor laboratory culture that the growth of $G$. coronopifolia can be markedly stimulated by nutrient enrichment in low temperature ranges $\left(20-22.5^{\circ} \mathrm{C}\right)$ and its growth temperature range was extended from $20-35$ to $15-35{ }^{\circ} \mathrm{C}$ by nutrient enrichment suggest that the significant biomass of $G$. coronopifolia during November 1999-January 2000 may be indicative of enhanced growth by highly enriched DIN concentrations in the water column. It has been shown that $G$. gracilis displayed a higher affinity for $\mathrm{NH}_{4}^{+}$than $\mathrm{NO}_{3}^{-}$at low temperatures (Smit, 2002). Although it was not the same species, the marked input of DIN, especially $\mathrm{NH}_{4}^{+}$, in November 1999-January 2000 may explain the significant growth of southern Taiwan G. coronopifolia in the cold months. All the field and experimental data together with the results of regression analysis indicate that the growth responses of G. coronopifolia to varying temperatures were influenced by nutrient availability, and temperature may be not one of factors affecting seasonal variations in areal biomass of $G$. coronopifolia from a coral reef of southern Taiwan.

Temperature may influence several physiological processes leading to enhance nutrient availability in algae; for example, temperature will influence the rate of diffusion and carrier-mediated uptake of nutrients. In Gracilaria tikvahiae, $\mathrm{NO}_{3}^{-}$uptake rates increased with increasing temperatures (Lapointe et al., 1984b). Our data showed that tissue $\mathrm{N}$ contents of $G$. coronopifolia increased up to the amounts near the critical N contents in August-September 1999, although seawater DIN concentrations were low during this high-temperature period. It is possible that high temperatures during summer months may stimulate the uptake rates of DIN in G. coronopifolia, and thus the enhancement of algal growth and the accumulation of tissue $\mathrm{N}$ even when seawater DIN concentrations were low in this period. This might also occur in L. papillosa in the summer. We thus hypothesize that the nutrient uptake of these two rhodophytes increased with increasing temperatures in southern Taiwan and thus alleviated $\mathrm{N}$ shortage due to growth stimulation by high temperatures in the summer months.

Except the impact of seasonally variable temperatures, variations in nutrient availability were also involved in the seasonality of southern Taiwan rhodophytes. Seawater DIN and SRP concentrations at the present study site were extremely high compared to coral reefs in Caribbean area, the Great Barrier Reef (Australia) and Hawaii (Lapointe and O’Connell, 1989; Lapointe, 1997; Larned, 1998; Schaffelke and Klumpp, 1998). This might be due to significantly expanded urban development and tourism in Hengchuan Peninsula in recent 10 years and we also found that the sewage waters were directly released to this southern Taiwan coral reef without treatments before January 2001. The riverine inputs by two large drainage outlets were an important nutrient source in this coral reef. Our investigations have shown that water nutrient concentrations were high in these two drainages and there were two peaks of nutrient concentrations occurring in June 1999 and May-June 2000, respectively, mainly caused by heavy precipitation (the data were described in Materials and methods). This was consistent with the temporal pattern of seawater nutrient concentration fluctuations that there were two peaks of seawater $\mathrm{NO}_{3}^{-}$concentrations in July 1999 and May-June 2000, respectively, and one peak of seawater SRP concentrations in July 1999. It strongly supports that nutrient $\left(\mathrm{NO}_{3}^{-}\right.$and SRP) was imported into this coral reef mainly by raining and riverine input, especially during the rainfall period (May-September). Evidently the coastal regions in the southern tip of Taiwan have become a highly eutrophic coral reef during 1999-2000. However, most seawater DIN and SRP concentrations during the survey were still lower than the nutrient thresholds for the maximum growth of G. coronopifolia $\left(16: 8: 1.2 \mu \mathrm{M}\right.$ of $\mathrm{NO}_{3}^{-} / \mathrm{NH}_{4}^{+}$/ 
$\mathrm{PO}_{4}^{3-}$ ), indicating that the growth of $G$. coronopifolia was nutrient-limited during the survey. On the other hand, it may also imply that $G$. coronopifolia biomass will increase if more nutrients are input in this system. This may be also occurred to $L$. papillosa that seawater nutrient concentrations were lower than the nutrient threshold in August-September, i.e. the early growth period of this rhodophyte, reflecting the nutrient limitation for L. papillosa growth in the hot summer months. However, the growth of L. papillosa at certain time of the year may suffer high nutrient injury, for example, $\mathrm{NH}_{4}^{+}$toxicity. The data showed that decreased growth rate of L. papillosa was found in response to nutrient concentrations higher than 8:4:0.6 $\mu \mathrm{M}\left(\mathrm{NO}_{3}^{-} / \mathrm{NH}_{4}^{+} / \mathrm{PO}_{4}^{3-}\right)$. In the cold months, $\mathrm{NH}_{4}^{+}$concentrations increased to approximately $4 \mu \mathrm{M}$ in mid November 1999 and reached a peak of $15 \mu \mathrm{M}$ in January 2000. It has been known that higher $\mathrm{NH}_{4}^{+}$ level was toxic to algal growth (Haines and Wheeler, 1978) and the uptake of $\mathrm{NO}_{3}^{-}$by algal cells can be inhibited by $\mathrm{NH}_{4}^{+}$(Haines and Wheeler, 1978; D'Elia and DeBoer, 1978; Thomas and Harrison, 1987; Smit, 2002). We suggest that high $\mathrm{NH}_{4}^{+}$concentrations ( $>4$ $\mu \mathrm{M})$ in the cold months may suppress the growth of $L$. papillosa. In this period, high APA indicated P deficit of $L$. papillosa. It is likely that the combination of low temperature, toxic DIN concentration and limited $\mathrm{P}$ availability accounted for the low abundance of $L$. papillosa during November-January.

These two rhodophytes from southern Taiwan displayed higher nutrient thresholds compared to $0.5-1.0 \mu \mathrm{M}$ DIN and 0.1 $\mu \mathrm{M}$ SRP for most macroalgae from tropical coral reefs (Bell, 1992; Lapointe, 1997,1999). A phaeophyte Sargassum baccularia from nearshore coral reefs in the Great Barrier Reef, Australia, also showed a higher nutrient threshold (5 $\mu \mathrm{M} \mathrm{NH}_{4}^{+}$and $0.5 \mu \mathrm{M} \mathrm{SRP}$ ) (Schaffelke and Klumpp, 1998). It is possibly the consequence of the adaptation of algal metabolisms to extra high $\mathrm{N}$ and $\mathrm{P}$ flux in southern Taiwan waters. On the other hand, the nutrient threshold may be over-estimated by the use

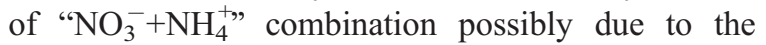
inhibition of $\mathrm{NO}_{3}^{-}$uptake by $\mathrm{NH}_{4}^{+}$, which reduces internal $\mathrm{N}$ pool and thus the following assimilation processes and growth. The nutrient thresholds for the maximum growth of $G$. coronopifolia were determined in this study as $16: 8: 1.2 \mu \mathrm{M}$ for $\mathrm{NO}_{3}^{-} / \mathrm{NH}_{4}^{+} /$ $\mathrm{PO}_{4}^{3-}$. Because a recent examination by G. gracilis has shown that the uptake of $\mathrm{NO}_{3}^{-}$can be suppressed up to $38 \%$ by $\mathrm{NH}_{4}^{+}$at concentrations above $5 \mu \mathrm{M}$ (Smit, 2002), it is likely that at the concentration for maximum growth $\left(16: 8: 1.2 \mu \mathrm{M}\right.$ for $\mathrm{NO}_{3}^{-} / \mathrm{NH}_{4}^{+}$/ $\left.\mathrm{PO}_{4}^{3-}\right)$, the utilization of oxidized $\mathrm{N}\left(\mathrm{NO}_{3}^{-}\right)$was inhibited by $8 \mu \mathrm{M} \mathrm{NH}_{4}^{+}$. This interaction of $\mathrm{NO}_{3}^{-}$and $\mathrm{NH}_{4}^{+}$may be also observed in L. papillosa. Here, the use of $\mathrm{NO}_{3}^{-}$and $\mathrm{NH}_{4}^{+}$in the present study was to simulate the actual DIN composition in southern Taiwan coral reef waters and the nutrient thresholds determined under mixed $\mathrm{N}$ conditions represent the situation of rhodophytes grown in this highly eutrophic southern Taiwan coral reef.

It has been known that most macroalgae can rapidly remove pulsed nutrient inputs from water columns before they can be detected (Fong et al., 1998), and algal tissue nutrient contents are thus used to infer limitation of either $\mathrm{N}$ or $\mathrm{P}$ (Wheeler and Björnsäter, 1992). So, algal tissue nutrient contents were analyzed in this study and compared to the critical and subsistence nutrient contents to comprehending seasonal variations in nutrient status of both algae. During the growing season, the comparison of tissue nutrient contents to critical and subsistence nutrient contents suggests that the severity of nutrient limitation was different between L. papillosa and G. coronopifolia. During the survey, most tissue $\mathrm{N}$ and $\mathrm{P}$ contents in G. coronopifolia were low and close to the subsistence levels, but half of tissue $\mathrm{N}$ and $\mathrm{P}$ contents in L. papillosa were $\geq$ the critical levels, indicating that L. papillosa has luxury $\mathrm{N}$ and $\mathrm{P}$ stores comparing to G. coronopifolia. This indicates that G. coronopifolia faced more severe nutrient limitation than $L$. papillosa on southern Taiwan. The above view is also supported by the higher nutrient thresholds of $G$. coronopifolia than those of L. papillosa obtained from the measurement of growth responses of macroalgae to nutrient enrichment of varying magnitude.

In addition, the type and severity of nutrient limitation of L. papillosa and G. coronopifolia were variable over time. The results that seawater SRP concentrations in 1999 were mostly higher than the threshold SRP concentration of L. papillosa and those in 2000 were near zero suggest that L. papillosa suffered more serious P limitation in 2000 than in 1999. During the growing season (June-November), L. papillosa was first P-limitation (the start of biomass increase) as supported by decreased tissue P contents 
and increased in $\mathrm{C} / \mathrm{P}$ and $\mathrm{N} / \mathrm{P}$ molar ratios before biomass reached the maximum, and during the period when the biomass started to decrease), it became Nlimited as suggested by a drop in tissue $\mathrm{N}$ contents, a rise in tissue $\mathrm{P}$ contents and a decrease in $\mathrm{C} / \mathrm{P}$ and $\mathrm{N} / \mathrm{P}$ molar ratios. Increased APA as the biomass reached the maximum in mid August also supported the primary P limitation of L. papillosa.

The growth of $G$. coronopifolia during the period of biomass increase (August 1999-January 2000) was also P-limited, as indicated by increased tissue $\mathrm{N}$ contents but concomitantly decreased tissue $\mathrm{P}$ contents. However, the severity of $\mathrm{P}$ limitation for $G$. coronopifolia growth was temporally variable during the period of biomass increase. There were marked drops in tissue $\mathrm{P}$ contents below the subsistence level in both mid September and December 1999, showing relatively serious $\mathrm{P}$ limitation at these 2 periods. Significantly increased APA of $G$. coronopifolia supports $\mathrm{P}$ limitation in the two periods. Because a marked increase in tissue $\mathrm{N}$ contents was found when serious $\mathrm{P}$ limitation occurred, it is possible that the growth limitation of $G$. coronopifolia by $\mathrm{P}$ at these two periods was caused by enhanced $\mathrm{N}$ availability. A significant increase of seawater DIN concentrations accompanied by increased biomass of $G$. coronopifolia seems to suggest that increased $\mathrm{N}$ input in December 1999 leads to enhanced growth and increased tissue N contents in G. coronopifolia, and thus, a relative $\mathrm{P}$ deficiency occurred in cold months when seawater SRP concentrations only showed a relatively small increase. The production of algae from eutrophic waters of carbonate-rich Jamaican reef was also limited by $\mathrm{P}$ (Lapointe, 1997). Littler et al. (1991) have concluded from the investigation of algal tissue nutrient contents and water-column nutrient concentrations among different geological systems in tropical waters of Republic of Seychelles that $\mathrm{P}$ is limited for algal production in carbonate-rich reefs. $\mathrm{P}$ limitation was also observed in other oligotrophic waters (Lapointe et al., 1987, 1992, 1993). However, $\mathrm{N}$ limitation has been recorded for several coral reefs (Lapointe et al., 1987; Littler et al., 1991; Larned, 1998). It is apparent that the type of nutrient limitation depends on the interactions between macroalgal species, environments, and season.

The present study shows that L. papillosa and $G$. coronopifolia from southern Taiwan had a relative high APA as compared to macroalgae from other places in the world (Lapointe et al., 1992; Schaffelke, 2001). It has been suggested that those algae with high APA and other mechanisms to acquire a range of nutrient are likely benefit from an increased nutrient supply caused by increased human activities (Schaffelke, 2001). The study of Schaffelke (2001) showed that high APA could compensate the relative Plimitation of macroalgae in response to significant $\mathrm{N}$-inputs in inshore reefs of the Great Barrier Reefs, Australia. Thus, these two opportunistic rhodophytes with high APA tend to bloom in nearshore reefs with extra high nutrient inputs in southern Taiwan.

Multiple factors involve in macroalgal seasonality. Factors such as light intensity may also influence the seasonal abundance of these 2 rhodophytes. Light is considered a primary factor affecting algal growth. It has been identified that the seasonal growth rates of Florida G. tikvahiae are correlated with seasonal variations in light intensity (Lapointe and Ryther, 1978). In this work, a sharp decrease in light intensity (1000 mol m${ }^{-2}$ month $^{-1}$, only $50 \%$ of the normal level) may be a cause for the sudden drop of $G$. coronopifolia biomass in April-July 1999. However, there was a decline of $G$. coronopifolia biomass occurring early in mid March-mid April 2000 even the light intensity remained around $2000 \mathrm{~mol} \mathrm{~m}^{-2}$ month ${ }^{-1}$, suggesting factors other than light leading to this biomass decline. The results of multiple regression analysis of field data have also shown that seasonal variations in monthly cumulative irradiance in the southern tip of Taiwan did not correlate with biomass abundance of both $G$. coronopifolia and $L$. papillosa. It is therefore suggested that light intensity might be not a factor influencing the seasonality of these two rhodophytes in southern Taiwan.

Our unpublished data showed that the abundance in grazers on reefs of Nanwan Bay of Hengchuan Peninsula (including sea urchins, Tripneustes gratilla (Linnaeus), Toxopneustes pileolus (Lamarck), Echinothrix spp. and herbivorous reef fishes Abudefduf spp., Dascyllus spp., Chaetodon spp.) significantly decreased in recent 5 years (1996-2000). A previous investigation on the temporal changes in population dynamics, diet and recovery of sea urchins (Trippneustes gratilla) in Hengchuan Peninsula from 1996 to 1997 reported that this sea urchin can consume the amount of algae (especially G. coronopifolia) up to $1 /$ 
10 of its body weight per day but its population density was only 0.0016 times that of 1984 caused by the human harvest of sea urchin gonad (Chao, unpublished data). Evidently the herbivorous pressure on coral reefs of Nanwan Bay in Hengchuan Peninsula decreased over the past decade. A recent study by Lapointe et al. (2004) suggests that bottomup control via nutrient enrichment is a primary factor regulating macroalgal biomass and taxonomic assemblages on coral reef, whereas grazing is more important in controlling relative species composition via dietary preferences. However, the seasonal variations in herbivorous pressure have not been determined at the present site and its relation to macroalgal abundance and composition and to nutrient enrichment-mediated macroalgal blooms is thus not clear.

In conclusion, the results of present investigation suggest that the coastal regions in the southern tip of Taiwan were already a highly eutrophic coral reef during the survey, and the differences in nutrient utilization strategy and temperature-dependent growth responses were responsible for variations in temporal abundance dynamics between $L$. papillosa and $G$. coronopifolia from a highly eutrophic coral reef in southern Taiwan. Our data showed that macroalgal blooms, especially G. coronopifolia, might increase if more nutrients are input in this system. Because macroalgal blooms on tropical waters are attributed to interactions among eutrophication, reduced herbivores (Lapointe, 1999; Lapointe et al., 2004) and other environmental parameters (Hughes and Connell, 1999), the role of temporal variations in herbivorous pressure and its interactions with other factors on the standing crops of both L. papillosa and G. coronopifolia still need to be addressed in the near future.

\section{Acknowledgements}

This study was part of the collaborative Kenting coral reef conservation study funded by the National Science Council (grant No. 89-2621-Z-110-1 and 902621-Z-110-1) and the Council of Agriculture (grant No. 90AS-1.4.5-FA-F1(22), 91AS-2.5.1-FA-F1(13) and 92AS-9.1.1-FA-F1(15)), Executive Yuan, Taiwan, Republic of China. We would like to thank the reviewer Dr. Brian E. Lapointe, Harbor Branch Oceanographic Institution, Fort Pierce, FL, USA for valuable suggestions. We are indebted to Dr. LeeShing Fang, the Present of the National Museum of Marine Biology and Aquarium, Pingtung, Taiwan, Republic of China, Dr. Keryea Soong, the professor in the Institute of Marine Biology, National Sun Yat-sen University, Kaohsiung, Taiwan, Republic of China, and Dr. Kwang-Tsao Shao, the research fellow in the Institute of Zoology, Academia Sinica, Taipei, Taiwan, Republic of China, for their assistance in this study. Thanks also to the Kenting National Park of Taiwan of Republic of China for assistance in field studies. [SS]

\section{References}

Banner, A., 1974. Kaneohe Bay, Hawaii: urban pollution and a coral reef ecosystem. Proc. 2nd Int. Coral Reef Symp., vol. 2, pp. $685-702$.

Bell, P.R.F., 1992. Eutrophication and coral reefs: some examples in the Great Barrier Reef lagoon. Water Res. 26, 553-568.

Breeman, A.M., 1988. Relative importance of temperature and other factors in determining geographic boundaries of seaweeds: experimental and phonological evidence. Helgol. Meeresunters. 42, 199-241.

Cuet, P., Naim, O., Faure, G., Conan, J.Y., 1988. Nutrient-rich groundwater impact on benthic communities of la Saline fringing reef (Reunion Island, Indian Ocean): preliminary results. Proc. 6th Int. Coral Reef Symp., vol. 2, pp. 207-212.

Dai, C.F., 1997. Assessment of the present health of coral reefs in Taiwan. In: Grigg, R.G., Birkeland, C. (Eds.), Status of Coral Reefs in the Pacific. Sea Grant Program. University of Hawaii, pp. $123-131$.

Davison, I.R., Pearson, G., 1996. Stress tolerance in intertidal seaweeds. J. Phycol. 32, 197-211.

Day, R.W., Quinn, G.P., 1989. Comparisons of treatments after an analysis of variance in ecology. Ecol. Monogr. 59, 433-463.

D'Elia, C.F., DeBoer, J.A., 1978. Nutritional studies of two red algae: II. Kinetics of ammonium and nitrate uptake. J. Phycol. 14, 266-272.

Fong, P., Boyer, K.E., Zedler, J.B., 1998. Developing an indicator of nutrient enrichment in coastal estuaries and lagoons using tissue nitrogen content of the opportunistic alga, Enteromorpha intestinalis (L. Link). J. Exp. Mar. Biol. Ecol. 231, 63-79.

Friedlander, M., Shalev, R., Ganor, T., Strimling, S., Ben-Amotz, A., Klar, H., Wax, Y., 1987. Seasonal fluctuations of growth rate and chemical composition of Gracilaria cf. conferta in outdoor culture in Israel. Hydrobiologia 151/152, 501-507.

Fujita, R.M., Wheeler, P.A., Edwards, R.L., 1989. Assessment of macroalgal nitrogen limitation in seasonal upwelling regions. Mar. Ecol., Prog. Ser. 53, 293-303.

Garbary, D., 1979. The effects of temperature on the growth and morphology of some Audouinella spp. (Acrochaetiaceae, Rhodophyta). Bot. Mar. 22, 493-498. 
Haines, K.C., Wheeler, P.A., 1978. Ammonium and nitrate uptake rates of the seaweeds Hypnea musicformis (Rhodophyta) and Macrocystis pyrifera (Phaeophyta). J. Phycol. 14, 319-324.

Hanisak, M.D., 1979. Nitrogen limitation of Codium fragile spp. tomentosoides as determined by tissue analysis. Mar. Biol. 50, $333-730$.

Hughes, T.P., 1994. Catastrophes, phase-shifts and large scale degradation of a Caribbean coral reef. Science 265, 1547-1551.

Hughes, T.P., Connell, J.H., 1999. Multiple stressors on coral reefs: a long-term perspective. Limnol. Oceanogr. 44, 932-940.

Hurtado-Ponce, A.Q., Umezaki, I., 1987. Growth rate studies of Gracilaria verrucosa (Gigartinales, Rhodophyta). Bot. Mar. 30, 223-226.

Hwang, R.L., Tsai, C.C., Lee, T.M., 2004. Assessment of temperature and nutrient limitation on seasonal dynamics among species of Sargassum from a coral reef in southern Taiwan. J. Phycol. 40, 463-473.

Lanzetta, P.A., Alvarez, L.J., Reinach, P.S., Candia, O.A., 1979. An improved assay for nanomole amounts of inorganic phosphate. Anal. Biochem. 100, 95-97.

Lapointe, B.E., 1987. Phosphorus- and nitrogen-limited photosynthesis and growth of Gracilaria tikvahiae (Rhodophyceae) in the Florida Keys: an experimental field study. Mar. Biol. 93, $561-568$.

Lapointe, B.E., 1997. Nutrient thresholds for bottom-up control of macroalgal blooms on coral reefs in Jamaica and southeast Florida. Limnol. Oceanogr. 42, 1119-1131.

Lapointe, B.E., 1999. Simultaneous top-down and bottom-up forces control macroalgal blooms on coral reefs. Limnol. Oceanogr. 44, 1586-1592.

Lapointe, B.E., O'Connell, J., 1989. Nutrient-enhanced growth of Cladophora prolifera in Harrington Sound, Bermuda: eutrophication of a confined, phosphorus-limited ecosystem. Estuar. Coast. Shelf Sci. 28, 347-360.

Lapointe, B.E., Ryther, J.H., 1978. Some aspects of the growth and yield of Gracilaria tikvahiae in culture. Aquaculture 15, $185-193$.

Lapointe, B.E., Dawes, C.J., Tenore, K.R., 1984a. Interactions between light and temperature on the physiological ecology of Gracilaria tikvahiae (Gigartinales: Rhodophyta): II. Nitrate uptake and levels of pigments and chemical constituents. Mar. Biol. 80, 171-178.

Lapointe, B.E., Tenore, K.R., Dawes, C.J., 1984b. Interactions between light and temperature on the physiological ecology of Gracilaria tikvahiae (Gigartinales: Rhodophyta): I. Growth, photosynthesis and respiration. Mar. Biol. 80, 161-170.

Lapointe, B.E., Littler, M.M., Littler, D.S., 1987. A comparison of nutrient-limited productivity in macroalgae from a Caribbean barrier reef and from a mangrove ecosystem. Aquat. Bot. 28, $243-255$.

Lapointe, B.E., Littler, M.M., Littler, D.S., 1992. Nutrient availability to marine macroalgae in siliciclastic versus carbonaterich coastal waters. Estuaries 15, 78-82.

Lapointe, B.E., Littler, M.M., Littler, D.S., 1993. Modification of benthic community structure by natural eutrophication: the Belize barrier reef. Proc. 7th Int. Coral Reef Symp., vol. 1, pp. 323-334.
Lapointe, B.E., Tomasko, D.A., Matzie, W.R., 1994. Eutrophication and trophic state classification of seagrass communities in the Florida Keys. Bull. Mar. Sci. 54, 696-717.

Lapointe, B.E., Barile, P.J., Yentsch, C.S., Littler, M.M., Littler, D.S., Kakuk, B., 2004. The relative importance of nutrient enrichment and herbivory on macroalgal communities near Norman's Pond Cay, Exumas Cays, Bahamas: a "natural" enrichment experiment. J. Exp. Mar. Biol. Ecol. 298, 275-301.

Larned, S.T., 1998. Nitrogen-versus phosphorus-limited growth and sources of nutrients for coral reef macroalgae. Mar. Biol. 132, $409-421$.

Lee, T.M., Chang, Y.C., Lin, Y.H., 1999. Differences in physiological responses between winter and summer Gracilaria tenuistupitata (Gigartinales, Rhodophyta) to varying temperature. Bot. Bull. Acad. Sin. 49, 93-100.

Littler, M.M., Littler, D.S., Titlyanov, E.V., 1991. Comparison of $\mathrm{N}$ - and P-limited productivity between high granitic island versus low carbonate atolls in the Seychelles Archipelago: a test of the relative dominance paradigm. Coral Reefs 10, 199-209.

Littler, M.M., Littler, D.S., Lapointe, E.E., 1992. Modification of tropical reef community structure due to cultural eutrophication: the southwest coast of Martinique. Proc. 7th Int. Coral Reef Symp., vol. 1, pp. 335-343.

Lüning, K., 1984. Temperature tolerance and biogeography of seaweeds: the marine algal flora of Helgoland (North Sea) as an example. Helgol. Meeresunters. 38, 305-317.

Murphy, J., Riley, J.P., 1962. A modified single solution method for the determination of phosphate in natural waters. Anal. Chim. Acta 27, 31-36.

Naim, O., 1993. Seasonal responses of a fringing reef community to eutrophication (Reunion Island, Western Indian Ocean). Mar. Ecol., Prog. Ser. 99, 137-151.

National Research Council, 2000. Clean Coastal Waters: Understanding and Reducing the Effects of Nutrient Pollution. National Academy Press, Washington, DC.

Pakker, H., Prudhomme van Reine, W.F., Breeman, A.M., 1994. Temperature responses and evolution of thermal traits in Cladophoropsis membranacea (Siphonocladales, Chlorophyta). J. Phycol. 30, 777-783.

Parsons, T.R., Maita, Y., Lalli, C.M., 1984. A Manual of Chemical and Biological Methods for Seawater Analysis. Pergamon Press, New York.

Schaffelke, B., 2001. Surface alkaline phosphatase activities of macroalgae on coral reefs of the central Great Barrier Reefs, Australia. Coral Reefs 19, 310-317.

Schaffelke, B., Klumpp, D.W., 1998. Short-term nutrient pulses enhance growth and photosynthesis of the coral reef macroalga Sargassum baccularia. Mar. Ecol. Pro. Ser. 170, 95-105.

Smit, A.J., 2002. Nitrogen uptake by Gracilaria gracilis (Rhodophyta) - adaptations to a temporally variable nitrogen environment. Bot. Mar. 45, 196-209.

Smith, V.R., 1980. A phenol-hypochlorite manual determination of ammonium-nitrogen in Kjeldahl digests of plant tissue. Commun. Soil Sci. Plant Anal. 11, 709-722.

Smith, V.R., Kimer, W.J., Laws, E.K., Brock, R.E., Walsh, T.W., 1981. Kaneohe Bay sewage diversion experiment: perspectives 
on ecosystem responses to nutrient perturbation. Pac. Sci. 35, $379-402$.

Sokal, R.R., Rohlf, F.L., 1981. Biometry: The Principles and Practice of Statistics in Biological Research, 2nd ed. W.H. Freeman, San Francisco.

Strickland, J.D.H., Parsons, T.R., 1972. A practical handbook of sea water analysis. Fish. Res. Board Can., Bull. 17, 310.

Thomas, T.E., Harrison, P.J., 1987. Rapid ammonium uptake and nitrogen ineractions in five intertidal seaweeds grown under field conditions. J. Exp. Mar. Biol. Ecol. 107, 1-8.
Tiessen, H., Moir, J.O., 1993. Total and organic carbon. In: Carter, M. (Ed.), Soil Sampling and Methods of Analysis. Lewis Publishers, Boca Raton.

Wang, Y.C., Pan, G.Y., Chen, L.C.-M., 1984. Studies on agarophytes: II. Field observations and growth of Gracilaria cf. verrucosa (Rhodophyta) in Shantou District, Guangdong, P.R.C.. Bot. Mar. 27, 265-268.

Wheeler, P.A., Björnsäter, B.R., 1992. Seasonal fluctuations in tissue nitrogen, phosphorus and N/P for five macroalgal species common to the Pacific northwest coast. J. Phycol. 28, 1-6. 